Historic, Archive Document

Do not assume content reflects current scientific knowledge, policies, or practices. 

a 5011

- A42 Resenve

\section{at) INd.}

\section{U.S. Forests in a Global Context}

Department of

Agriculture

Forest Service

David J. Brooks

Rocky Mountain

Forest and Range

Experiment Station

Fort Collins

Colorado 80526

General Technical

Report RM-228

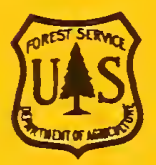

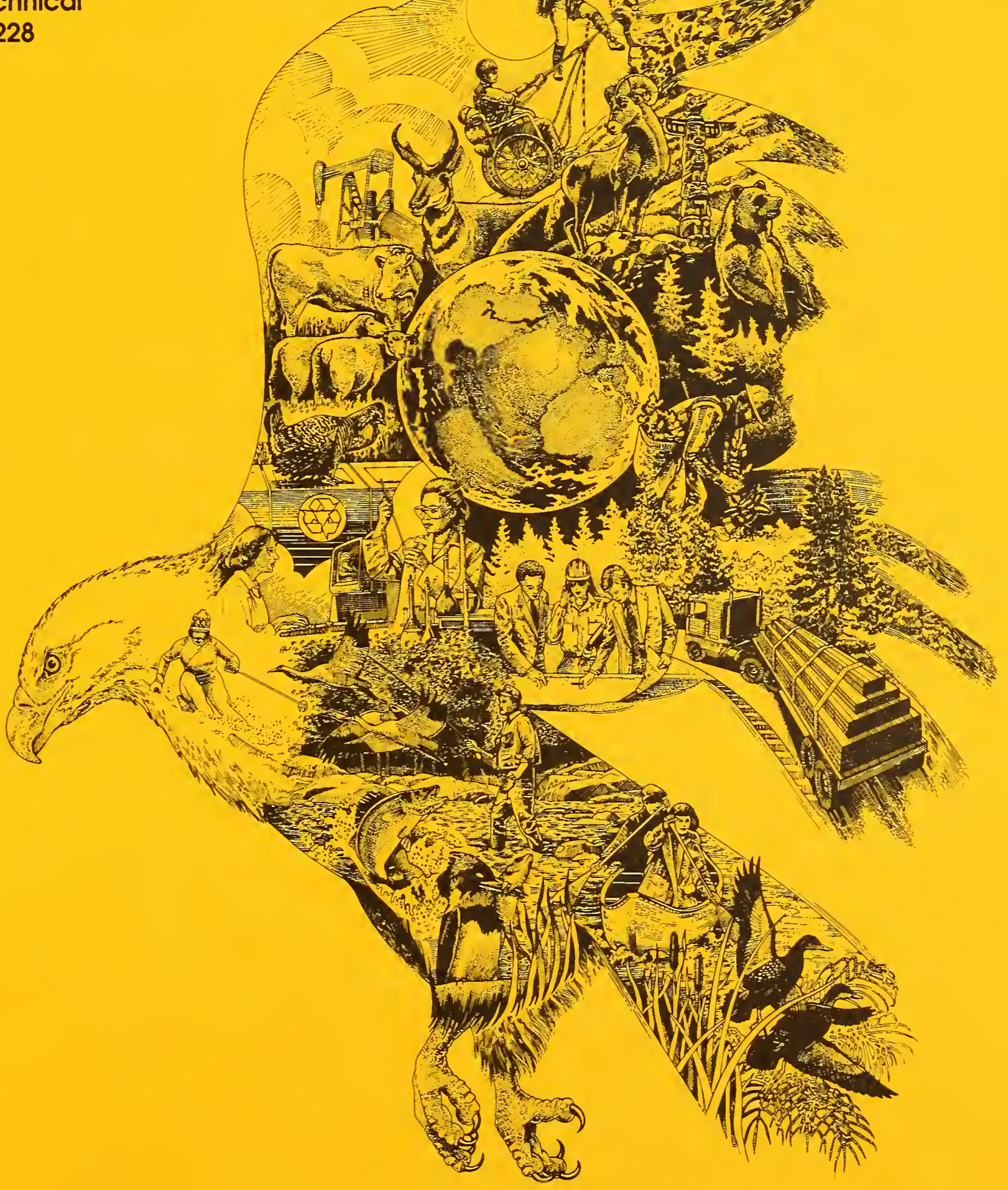




\begin{abstract}
Brooks, David J. 1993. U.S. forests in a global context. Gen. Tech. Rep. RM-228. Fort Collins, CO: U.S. Department of Agriculture, Forest Service, Rocky Mountain Forest and Range Experiment Station. 24 p.

World forest resource data as of 1990 are summarized, and patterns of forest use are briefly described. Forest resource conditions and use in the United States are compared to global data. Global forestry issues for developed and developing countries are discussed, and two issues specific to the United States are examined. The first is whether U.S. forest resource policies cause environmental problems in other countries. The second is consideration of the elements of U.S. experience with forests that can be transfered to benefit other countries, especially developing countries.
\end{abstract}

Keywords: Forest resources, deforestation, world trade, environmental impacts, policy

USDA policy prohibits discrimination because of race, color, national origin, sex, age, religion, or handicapping condition. Any person who believes he or she has been discriminated against in any USDA-related activity should immediately contact the Secretary of Agriculture, Washington, DC 20250.

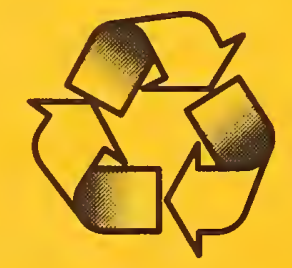

This publication was printed on recycled paper. 


\title{
U.S. Forests in a Global Context
}

\author{
David J. Brooks, Research Forester \\ Pacific Northwest Research Station 1
}


Contents

Page

Introduction

Forests on the Global Agenda

Objectives and Limits

Global Forestry Literature

Global Forest Resources

Social and Economic Context

Forest Resource Data .

Plantation Forests

Patterns and Trends in Forest Use.

Timber.

Non-timber Forest Products

Services

Comparing U.S. and Global Conditions

Global Forestry Issues

Does U.S. Resource Policy Export Environmental Problems?

Exporting U.S. Experience

Summary

Literature Cited
1

1

2

2

4

4

5

7

9

.9

13

13

14

17

18

19

20

21 


\title{
U.S. Forests in a Global Context
}

\author{
David J. Brooks
}

\section{Introduction}

"Our own forest resources are being depleted. Our high-grade hardwoods are almost exhausted, and manufacturers are looking to the tropics and elsewhere for foreign sources of supply. The tropical forests contain valuable timber, yet data regarding the kinds and qualities are not readily available. The last great bodies of softwoodthose on the Pacific Coast-will soon be gone. Lumbermen of this and other countries are thinking seriously of getting timber from the great but little-known forests of Asiatic Russia. But can Russia meet the demand? Without accurate knowledge of the world's timber resources there can be no intelligent policy of forest conservation."

\section{Gifford Pinchot in Zon and Sparhawk (1923;p.vii)}

\section{Forests on the Global Agenda}

The Forestand Rangeland Renewable ResourcePlanning Act (RPA) requires periodic assessments of the condition of, and future for the Nation's natural resources. The attention paid to the role of the United States in the global community has largely been limited to consideration of commodity trade; international issues were raised in the context of the United States as a consumer of imported products, or as a competitor in foreign markets. Although international trade continues to be an important consideration in assessing trends in domestic renewable resources, the scope of international resource issues has broadened considerably.

In the past 20 years, and especially in the past decade, increasing public attention has been paid to a variety of global environmental issues, including climate change, ozone depletion, and loss of biological diversity. Regional and local forest resource and environmental issues, such as the impacts of industrial pollution and the contribution of natural resources to social and economic development, must be considered, also. The environmental consequences of human actions can be widespread, enduring, and can accumulate over time. Because resources are finite, and all competing demands cannot be met, the social challenges of global environmental problems will increase along with the ecological challenges.

Forestry issues illustrate these developments. Nearly all of the large-scale, prominent issues of the global environment involve forests. Deforestation contributes to loss of species and accumulation of atmospheric carbon; commodities from forests support economic growth and social development; the distribution and character of forests are likely to be affected by significant climate change; reforestation and afforestation may mitigate global warming. Forests currently cover onethird of the earth's land area, and play a critical role in sustaining global environmental systems. At the same time, forests have a direct role in sustaining human communities by providing fuel, food, commodities, and income. As a result, forests are receiving unprecedented attention in international environmental debates.

One consequence of increased international attention to the broad questions of forest use and condition has been a merging of domestic and global issues; the rhetoric and content of domestic resource policy debates is now strongly influenced by debates in the global arena. This is an extension of a process observed in the United States over the past half-century; local and regional conflicts over management and use of public resources have been increasingly nationalized. Local interests are less able to control use of federal resources. Identification of global forestry issues takes this process one step further: forest resource use and management in all countries is now a legitimate subject for international discussions.

The United Nations Conference on Environment and Development (UNCED), held in Rio De Janeiro, Brazil, in June 1992, and its accompanying preparatory discussions, was a major event in the emergence of forest issues in international environmental debates. The importance and complexity of forest issues was demonstrated in efforts to develop an international agreement on 
forests (Maini 1991) for signing at UNCED. Although an international treaty on forests was not signed, agreement on forest issues is reflected in three products of the UNCED meeting: (1) the acceptance of a report on forest conditions with an assessment of threats to forests (United Nations 1992); (2) adoption, by consensus, of an approach to integrate national actions and international cooperation to combat deforestation (Agenda 21), ${ }^{2}$ and (3) adoption, by consensus, of a statement of "forest principles." 3

For the United States to participate in formulating international policy on forests, it must understand global forestry issues. This must include understanding conditions in the United States relative to those in other countries, as well as understanding critical differences in biological, economic, and social factors that determine these conditions. Similarly, the ability of the United States to formulate sound domestic resource policies also depends on its understanding of global issues. Domestic conditions directly affect and are affected by international developments.

\section{Objectives and Limits}

This report summarizes United States and global forest resourcedata, and discusses global forest resource issues. The objective is to identify key issues and to help develop an international context for U.S. resource policies. Existing data and literature are used to characterize patterns and recent trends, and to improve understanding of key issues. The primary objective is to demonstrate the importance of global forest resource issues to the United States, thereby providing a starting point for more in-depth assessments of the scope, content, and opportunities for the United States in global forest resource problems. These assessments, in turn, will provide the scientific and technical information that can be used in formulation of U.S. policies and programs.

In this context, several questions need to be addressed. What are the significant issues of global forestry? How do the forest resources of the United States compare to those in the rest of the world? How does the use of forest resources in the United States compare to

\footnotetext{
${ }^{2}$ Agenda 21, Chapter 11. Combatting deforestation. Advance copy. Conches, Switzerland: United Nations Conference on Environment and Development, 14 June 1992; 22 p. 1.

${ }^{3}$ Non-legally binding authoritative statement of principles for a global consensus on the management, conservation and sustainable development of all types of forests, A/CONF.151/6/Rev. 1 , United Nations Conference on Environment and Development, 13 June 1992.2.
}

the rest of the world? What is, or what should be the role of the United States as a steward of forest resources, and as an advocate of a set of political, economic, and resource management principles? What is, or what should be the international role of the United States as a producer and consumer of forest products?

\section{Global Forestry Literature}

Literature on world forests can be organized into three broad categories: ${ }^{4}(1)$ comprehensive summaries of resources; (2) outlook studies describing the supply of, and demand for forest products (almost exclusively focused on timber products); and (3) studies that address regional issues, such as tropical deforestation, in a global context. Although attention paid to global forests is not new, the focus of the literature has changed substantially in the past 20 years, and the volume of literature has increased in the past decade. Environmental concerns, such as the role of forests in sequestering carbon, the response of forests to atmospheric pollution, and the importance of forests in providing habitat for flora and fauna, receive more attention than the availability of timber for industrial products. Despite this shift away from Pinchot's concerns, a reading of global forestry literature dating back 100 years or more reveals a sobering similarity of issues. For example, a comparison of Marsh (1884) and United Nations (1992) illustrates the enduring nature of many global forestry problems: the effects of forest clearing on climate, the need to maintain environmental services, and the need to assure continuing availability of commodities from forests.

Global forest resources.-Zon (1910), and Zon and Sparhawk (1923) produced comprehensivesurveys and assessments of forest resources as of the early part of the 20th century. Paterson (1956) summarized forest area data and "potential productivity" of world forests as of the early 1950s. Beginning in 1953, the Food and Agriculture Organization (FAO) of the United Nations (UN) began publishing regular assessments of world forest resources. The assessment of world resources in the early 1960s (FAO 1963) raised concerns over patterns and trends in forest area change and forest utilization;

\footnotetext{
${ }^{4}$ The reference here is to literature broadly addressing issues of global forests; therefore, this survey does not include the extensive literature that focuses on issues of particular countries or regions, or the international literature of forestry science that reports in depth results of the application of social and biological sciences to forests. Although these, too, can be termed "global forestry literature" they are beyond the scope of the present exercise.
} 
these concerns have been reinforced in nearly every subsequentstudy. Persson (1974) compiled world forest resource data as of the early 1970s; FAO (1985) summarized world forest area data for 1980. Although these studies provide considerable detail for individual countries, inconsistencies ranging from the definition of terms to changing country borders make it difficult to use these sources even to identify broad trends and patterns. Table 1 summarizes world forest area data from these studies; contrary to expectation, this compilation shows no clear trend in world forest area over the past 40 years.

More recent assessments of world forests have increased the quality and quantity of information, partly by focusing the scope. Sommer (1976) assessed tropical forest resources for in the early 1970s; Persson (1977) focused on the forest resources of Africa. Lanly (1982) provided a comprehensive assessment of tropical forest resources, as of 1980; FAO (1988) extended this to include all developing countries. FAO (1976) and UNECE (1985) provided comprehensive data on forest resources in Europe and the ECE region (Europe, North America, and the Soviet Union). Lanly and Clement (1979), Sedjo (1980, 1981), Evans (1986), and Grainger (1988) provided an increasingly detailed picture of plantation forestry around the world. The most recent data on the world's temperate forests in developed countries were reported by UN-ECE (1992). Food and Agriculture Organization (1992b) summarized preliminary data from the companion effort to assess the world's tropical forests. Allan and Lanly (1991), and Dembner (1991) summarized the preliminary data from both the temperate and tropical zone assessments.

In addition to broad-based assessments and compilations of data, there have been efforts to synthesize assessment data and improve understanding of global forest resource conditions, and global forestry issues. Somerecentexamples includeSedjoand Clawson(1984), Osara (1984), Sedjo (1987), Mather (1987), Laarman and Sedjo (1992), and United Nations (1992). World Re-

Table 1. Estimates of world forest area (million hectares), 1950-1990.

\begin{tabular}{lll}
\hline Year & Forest area & Source \\
\hline 1950 & 3,893 & Paterson (1956) \\
1960 & 4,126 & FAO (1963) \\
1970 & 4,030 & Persson (1974) \\
1980 & 4,321 & FAO (1985) \\
1990 & 4,047 & FAO (1992b); UN-ECE (1992) \\
\hline
\end{tabular}

aecause of the use of different methods and defintions, these data cannot be taken as representing trends over time. sources Institute (1992) drew on data from a variety of sources to provided a comprehensive picture of forests and other world resources as of the mid-1980s. Laarman and Sedjo (1992) and Mather (1990) provided a comprehensive summary of global forest resources and resource issues; although the data used are no longer the most up-to-date, the summary of trends, issues, and policy implications remains valid.

Outlookstudies.-Many of the world forest resource assessments done over the past 50 years also have tried to predict area change, or project production and consumption of forest products. FAO $(1982,1986,1991 b)$ is a series of comprehensive projections of the supply and demand for timber and major forest products. Other recent world timber outlook studies include Kallio and others (1987), Kuusela (1987), and Arnold (1991). Each of these studies provides an outlook for world demand for timber, with varying degrees of detail on the type of products and location of production and consumption. FAO (1967) and UN-ECE (1986) are examples of regional studies, the former for Africa, and the latter for Europe. Outlook studies for particular commodities include fuelwood supplies in developing countries (de Montalembert and Clement 1983), tropical timber production (Pringle 1976), and production of high-value hardwoods from tropical plantations (Grainger 1988).

World forestry issues.-Issues of tropical forests are prominent in much of the recent literature on world forests, although temperate forests and, especially, boreal forests are receiving more attention. United Nations (1992) summarized current issues regarding the condition, use, and value of forests, and provided an assessment of threats to world forests. This assessment is particularly significant, because it was accepted at UNCED as a suitable basis to begin negotiations on forest principles, and as background for the Agenda 21 chapter on forests. Issues identified include: management of forests for production of commodities; management of forests for conservation; accelerating rates of deforestation; the need to asses the magnitude and extent of forest degradation from fires, pollution, and unsustainable utilization; and the need to understand better the extent and impact of afforestation. Although distinctions are made between tropical and temperate forests in terms of the pervasiveness or the severity of problems, these issues are genuinely global, because impacts are felt broadly, or because solutions must originate collectively.

Sharma (1992) expanded the summary provided in United Nations (1992), compiling contemporary work 
addressing the core issues of conservation and management of world forests: the importance of forests, the nature and causes of forest problems, and management and policy options to address these problems. Developing countries and tropical forests are the central focus of most of the contributions. Panayotou and Ashton (1992) also were concerned with tropical forests, but focused on the need for-and approaches to-value all goods and services of tropical forests, not just industrial timber products. BothSharma (1992) and Panayotouand Ashton (1992) offered information, insights, and analytical approaches that can be used in examining problems in temperate and boreal forests. For example, analytical methods that yield better estimates of the value of the full range of forest products and services can be applied to both temperate and tropical forests. Despite this, issues of tropical forests dominate much of the global forestry literature.

The processes, consequences, and causes of tropical deforestation have received much popular as well as scientific attention, resulting in extensive literature on this subject alone. Barraclough and Ghimire (1990) summarized much of the literature on the causes of deforestation in developing countries; Guppy (1984) provided a broad summary of the issue of tropical deforestation, with a socio-political context. Grainger (1990), Mahar (1989), and Allen and Barnes (1985) were among the many studies that examined in detail the processes and consequences of tropical deforestation. Richards and Tucker (1988) and Tucker and Richards (1983) provided an historical context for understanding factors in deforestation in both the tropical and temperate zones over the past two centuries.

\section{Global Forest Resources}

Efforts to compile and display global forest resource data begin with caveats and disclaimers: data are incomplete, inconsistent and, as a result, often inconclusive. Table 1 shows estimates of world forest area reported in studies done over the period 1950-1990. Instead of displaying meaningful trends, these data illustrate the variability of estimates from different sources, using different methods. Although disclaimers still are necessary, global forestry data have never been better. Significant improvements in the scope and consistency of forest resource data have resulted from the Forest Resources Assessment 1990 project of FAO (FAO 1992; UN-ECE/FAO 1992). World Resources Institute (1992) incorporated some early results from the Forest Resources Assessment 1990 effort, and, by extending well beyond forest resources, provided a context for evaluating resource trends. As a result of these efforts, we are better able to assess broad-based conditions and trends in global forests.

There are several ways that global forest resource data can be compiled, aggregated, and displayed; each reveals important dimensions of forest conditions and trends. However, each aggregation masks key differences; therefore, it is important to display data using at least three approaches to aggregation: geography, ecology, and economy. Political and geographic boundaries typically form the basis for identification of common interests and common actions in regional and multinational policy formulation; therefore, political boundaries are a logical basis for displaying global resource data. However, because concern for changes in ecological conditions underlies many prominent global forestry issues, patterns and trends in forest resource data also must be displayed by broad ecological zones. For most data, details are provided for the boreal, temperate and tropical zones. Because forest resource use, value, and policy objectives depend greatly on economic factors, patterns and trends based on stage of economic development (developed and developing countries) provide important information.

The tropical zone includes all countries with significant land area between the Tropic of Cancer, in the Northern Hemisphere, and the Tropic of Capricorn, in theSouthern Hemisphere. The temperate zone includes all countries outside this broad band around the Equator; temperate zone data are divided further into the boreal zone and the other temperate forests. The boreal zone is the northernmost temperate forest, generally including Canada, Russia, and the Nordic countries.

\section{Social and Economic Context}

Patterns of economic development and, especially, population growth set the context for a discussion of global forestry issues. In addition to their role in global environmental systems, forests have provided products that support economic development, and a reserve of land that can be converted to agricultural use. Population distribution (table $2 \mathrm{a}$ ) and population growth rates (table 2b) partly illustrate the type and the magnitude of pressures on global forests that can be expected to continue or increase over the next few decades. In general, as the world's population becomes increasing- 
Table 2.-World population, 1990.

2a.-World population (millions) by economic group, and residence, 1990.

\begin{tabular}{lrrrr}
\hline $\begin{array}{l}\text { Economic } \\
\text { group }\end{array}$ & Total & Urban & Rural & $\begin{array}{c}\text { Percent } \\
\text { urban }\end{array}$ \\
\hline $\begin{array}{l}\text { Developed } \\
\text { of which: }\end{array}$ & 1,265 & 914 & 351 & 72.3 \\
$\quad \begin{array}{l}\text { United States } \\
\begin{array}{l}\text { Developing } \\
\text { World }\end{array}\end{array}$ & 249 & 184 & 65 & 74.0 \\
& 5.028 & 1.485 & 2,543 & 36.9 \\
& 5.293 & 2.399 & 2.984 & 45.3
\end{tabular}

2b.-Annual growth (percent) in world population, by economic group and residence, 1975-1990.

\begin{tabular}{lccc}
\hline $\begin{array}{l}\text { Economic } \\
\text { group }\end{array}$ & Total & Urban & Rural \\
\hline Developed & 0.7 & 1.0 & -0.1 \\
Developing & 2.0 & 4.2 & 1.0 \\
World & 1.6 & 2.8 & 0.8 \\
\hline
\end{tabular}

Source: FAO (1991b)

ly urban, the demand on forests can be expected to shift toward industrial products and environmental services. Greater interest in, and demand for environmental services from forests does not eliminate demand for commodities; it does, however, alter the composition of demand, and fundamentally affects the determination of socially and environmentally acceptable production methods. Definitions and perceptions of sustainability can be expected to vary with patterns of economic development.

Rapidly growing urban populations in developing countries intensify pressures on the economies, the infrastructure, and the land bases (including forests) of these countries. More than one-half of the world's population, and two-thirds of the population of developing countries still lives in rural conditions. More important, roughly $80 \%$ of the world's population is relatively poor, and relies on forests for basic sustenance-primarily, fuel and land for growing crops. The time horizon over which sustainability is defined is short under such circumstances, and its characteristics-sustaining what, for whom-aredominated by thetangiblenecessities of life.

\section{Forest Resource Data}

Forests cover just over 4 billion hectares (about 10 billion acres) of the earth's surface, about $30 \%$ of the land area. This includes all types of forests: closed and open natural forest, forest plantations, and other woodland. Forest is defined as land with tree cover growing to more than 7 meters in height, and a density of about $20 \%$ or more of the land area (UN-ECE 1992). Shrub, scrub, and brush land cover about 1 billion hectares (United Nations 1992).

Tables 3-5 summarize data on world forest area, population, and economic development. Table 3 shows population, population growth rate, and forest area in 1990, and forest area changes 1980-90 by geographic region. Table 4 also shows geographic divisions, but also shows broad land use patterns for most of the countries or regions shown in table 3; relative forest area can be compared to the area of agricultural and other land. "Other land" includes developed areas as well as desert and fallow land. Table 5 displays forest area and population data by broad ecological zone and economic groupings.

Table 3.-Population, population growth rate, and forest area in 1990 , and average annual change in forest area 1980-1990, by country or geographic region.

\begin{tabular}{|c|c|c|c|c|}
\hline \multirow[b]{2}{*}{ Region } & \multicolumn{2}{|c|}{ Population } & \multicolumn{2}{|c|}{ Forest area } \\
\hline & Total & $\begin{array}{l}\text { Annual } \\
\text { growth rate }\end{array}$ & Total & $\begin{array}{r}\text { Aver. annual } \\
\text { change, } \\
1980-1990\end{array}$ \\
\hline & millions & percent & million ha. & percent \\
\hline Asia $^{\circ}$ & $3,071.6$ & 2.0 & 484.5 & $-1.2^{f}$ \\
\hline Latin America & 448.3 & 2.0 & 919.4 & $-0.9^{f}$ \\
\hline Africa $^{a}$ & 647.5 & 3.0 & 604.3 & $-0.8^{4}$ \\
\hline North America & 275.7 & 1.0 & 751.4 & $-0.0^{9}$ \\
\hline United States & 248.7 & 0.8 & 298.1 & $-0.1^{\mathrm{h}}$ \\
\hline Nordic $^{b}$ & 17.8 & 0.1 & 61.0 & $+0.0^{9}$ \\
\hline Europec & 547.1 & 0.2 & 134.0 & +0.1 \\
\hline C.I.S. ${ }^{d}$ & 287.7 & 0.7 & 941.5 & +0.2 \\
\hline Oceania & 20.4 & 0.2 & 153.1 & nc \\
\hline World & 5.316 .1 & 1.7 & $4,047.1$ & -0.4 \\
\hline
\end{tabular}

nc $=$ no change

ancludes tropical and temperate zone countries.

'Finland, Norway, and Sweden.

'Excluding Nordic countries and C.I.S. countries; including Turkey.

${ }^{\circ}$ Commonwealth of Independent States.

eAustralia and New Zealand only.

Data for tropical countries.

gLess than .05\%.

${ }^{\text {h}}$ Area data are for 1992; average annual net change in forest area 1977-87 was about -0.1 percent, but forest area increased slightly 1987-92.

Sources: FAO (1992b), UN-ECE (1992), World Resources Institute (1992), Sharma (1992), Powell and others (in press). Population data differ slightly from table 2 because of the use of different sources. 
Table 4.-Comparison of land use in selected countries and regions, about 1985.

\begin{tabular}{|c|c|c|c|c|c|c|c|}
\hline $\begin{array}{l}\text { Country/ } \\
\text { region }\end{array}$ & $\begin{array}{l}\text { Popul- } \\
\text { ation }\end{array}$ & $\begin{array}{l}\text { Total } \\
\text { forest }\end{array}$ & $\begin{array}{l}\text { Timber- } \\
\text { land }\end{array}$ & $\begin{array}{l}\text { Other } \\
\text { forest }\end{array}$ & $\begin{array}{l}\text { Agri- } \\
\text { cultural } \\
\text { land }\end{array}$ & $\begin{array}{l}\text { Othe } \\
\text { land }\end{array}$ & $\begin{array}{l}\text { Total } \\
\text { land }\end{array}$ \\
\hline & \multicolumn{2}{|l|}{ millions } & \multicolumn{4}{|c|}{ million hectares } & \\
\hline \multicolumn{8}{|l|}{ United } \\
\hline States & 249 & 296.0 & 209.6 & 86.4 & 397.8 & 218.7 & 912.5 \\
\hline Canada & 27 & 436.4 & 264.1 & 172.3 & 67.2 & 413.1 & 916.7 \\
\hline Nordic & 17 & 59.9 & 48.3 & 11.6 & 9.8 & 42.8 & 112.4 \\
\hline Europe ${ }^{a}$ & 539 & 133.9 & 84.6 & 49.3 & 232.2 & 73.2 & 439.5 \\
\hline Japan & 124 & 25.2 & 23.9 & 1.3 & 5.3 & 7.2 & 37.7 \\
\hline Africa & 648 & 604.3 & na & na & 1.077 .31 & $1,282.5$ & $2,964.1$ \\
\hline $\begin{array}{l}\text { Asiab } \\
\text { Latin }\end{array}$ & 2,948 & 459.8 & na & na & 1.143 .51 & $1,077.8$ & $2,693.5$ \\
\hline America & 448 & 919.4 & na & na & 752.0 & 380.4 & $2,051.8$ \\
\hline
\end{tabular}

Excluding the Nordic countries (Finland, Sweden, Norway), but including Turkey.

'Excluding Japan.

Source: UN-ECE (1992, 1986, 1985), World Resources Institute (1992).

One-half of the world's forests, and $80 \%$ of theworld's population are in Asia, Latin America, and Africa. These are predominantly, although not exclusively, developing countries, and the forests are predominantly, although not exclusively, tropical. About one-fourth of the world's forests, nearly one-half of the world's tropical forests, and more than one-half of the world's wet tropical forests (rain forest, and moist lowland forest) are in Latin America. Brazil accounts for about twothirds of the forest area of Latin America. About 35\% of all tropical forests, and $30 \%$ of the wet tropical forests are in Africa; Zaire accounts for about $30 \%$ of the forest land of Africa. In contrast to both Latin America and Africa, only slightly more than one-half of the forest land of Asia is tropical forest; nearly all of the tropical forest in Asia is wet tropical forest. Indonesia accounts for about $45 \%$ of the tropical forest in Asia; Papua New Guinea and Malaysia together account for about $20 \%$ of the tropical forest. More than one-half of the temperate forest of Asia is in China.

Nearly $58 \%$ of the world's forests are in the temperate zone; boreal forests account for more than one-third of the world's forests and more than $60 \%$ of the nontropical forest. Table 5 displays sharp contrasts in the distribution of forests and population across ecological zones and economic groups. Countries in the boreal region account for slightly more than $5 \%$ of the world's population, but nearly $35 \%$ of the world's forest area; developed countries in the temperate zone (including
Table 5.-Forest area, population, and forest area per capita, by ecological zone and economic grouping, 1990.

\begin{tabular}{|c|c|c|c|}
\hline & Forest area & Population & Forest/capita \\
\hline & million hectares & millions & hectares/cap. \\
\hline $\begin{array}{l}\text { Temperate } \\
\text { Of which: }\end{array}$ & 2,333 & 2,849 & 0.82 \\
\hline Developed & 2,064 & 1,265 & 1.63 \\
\hline Developing & 269 & 1,584 & 0.17 \\
\hline $\begin{array}{l}\text { Of which: } \\
\text { Boreal }^{\text {b }}\end{array}$ & 920 & 307 & 3.00 \\
\hline Other temperate & 1,413 & 2,289 & $\begin{array}{l}3.00 \\
0.62\end{array}$ \\
\hline Tropicalc & 1.715 & 2,697 & 0.69 \\
\hline Total & 4,047 & 5,293 & 0.76 \\
\hline \multicolumn{4}{|c|}{$\begin{array}{l}\text { "Countries in the Northern and Southern Hemispheres outside of } \\
\text { the tropical zone. }\end{array}$} \\
\hline \multicolumn{4}{|c|}{$\begin{array}{l}\text { 'Includes Canada, Finland, Norway, Sweden, and Russia, and } \\
\text { Alaska. }\end{array}$} \\
\hline \multicolumn{4}{|c|}{$\begin{array}{l}\text { "Countries within the tropical zone (lying between the Tropic of } \\
\text { Cancer and the Tropic of Capricorn). }\end{array}$} \\
\hline \multicolumn{4}{|c|}{ Sources: FAO (1992), UN-ECE (1992), FAO/AGROSTAT-PC. } \\
\hline
\end{tabular}

those in the boreal region) have more than double the world average endowment of forests. Data for the developing countries in the temperate zone are dominated by China, where forest area is less than one-fifth the world average.

Between 1980 and 1990, the area of forest world-wide declined by $4 \%$ to about 0.8 hectare per capita; this is less than one-half the estimated 2.0 hectares of forest per person in the 1930s (Mather 1987), and about one-third the world forest endowment at the beginning of the century. Deforestation-cumulated across all regionshas occurred at rates estimated to be from $0.3 \%$ per year to $0.6 \%$ per year ( 11 million to 20 million hectares per year) in the past two decades, while population has grown at more than $1.5 \%$ per year. A gain of about 20 million hectares in temperate forest over the period 1980-90 was more than offset by a reduction of about 170 million hectares in tropical forest.

Table 3 illustrates theoften-observed correspondence between high rates of population growth, poverty, and loss of forest area. As Barraclough and Ghimire (1990) pointed out, however, it is simplistic and uninformative to suggest that population growth or poverty alone cause deforestation; instead, deforestation must be understood as the outcome of complex interaction among social and natural systems. The relevant factors that explain deforestation include land tenure, population density, agricultural policies, macroeconomic policies, trade policies, the type and duration of forest distur- 
bance, and the biological characteristics of the forest ecosystem (FAO 1992; Downing and others 1992; Grainger 1990; Repetto and Gillis 1988).

Table 6 provides detail on the amount and rate of deforestation by forest types in the tropical zone. Wet tropical forests account for the majority of tropical forest area and tropical deforestation; however, the rate of deforestation is most severe in the dry tropical forest, where population pressure and environmental stress are combined. Nevertheless, more than one-half of the total reduction in tropical forests occurs in countries with the largest area of remaining forest; one-half of the total loss was in Latin America, most of that in Brazil. Regional data mask high rates of deforestation in selected countries, and in regions of countries. Rapid forest loss, with accompanying social and ecological problems, occurred in parts of Mexico, Central America, West Africa, and continentalSoutheast Asia (FAO1992). Comparison of current (1990) and previous estimates of tropical deforestation indicates that there has been a substantial increase in the rate of deforestation in nearly all tropical zones. Allan and Lanly (1991) suggested that the rate of increase may not be a dramatic as it first appears (about a 50\% increase). Nevertheless, 170 million hectares are estimated to have been lost in the period 1980-1990, compared to about 120 million hectares lost in the period 1976-80.

About two-thirds of the world's forests are publicly owned. Although only slightly more than one-half of temperate forests are in public ownership, nearly all tropical forests are in public or communal ownership (table 7). The United States, Japan, and the Nordic

Table 6.-Tropical forest area in 1990, area deforested 1981-1990, and deforestation rate, by forest type.

\begin{tabular}{|c|c|c|c|}
\hline Forest type ${ }^{a}$ & $\begin{array}{l}\text { Total } \\
\text { area }\end{array}$ & $\begin{array}{c}\text { Average annual } \\
\text { deforestation, } \\
1981-1990\end{array}$ & $\begin{array}{l}\text { Annual } \\
\text { deforestation } \\
\text { rate }\end{array}$ \\
\hline \multicolumn{3}{|c|}{ million hectares } & percent \\
\hline $\begin{array}{l}\text { Total tropical } \\
\text { Lowland }\end{array}$ & 1.714 .9 & 16.9 & 0.9 \\
\hline Rain forest & 655.5 & 4.9 & 0.7 \\
\hline Moist forest & 626.4 & 7.3 & 1.1 \\
\hline Dry deciduous & 212.9 & 2.1 & 0.9 \\
\hline Very dry & 39.5 & 0.2 & 0.7 \\
\hline Desent & 2.5 & 0.1 & 4.0 \\
\hline Upland & & & \\
\hline Hill and montane & 178.1 & 2.3 & 1.1 \\
\hline
\end{tabular}

aFor definitions of forest types used in the assessment of the tropical zone see FAO (1992).

Source: FAO (1992).
Table 7.-Percent ownership of forest land in selected countries and regions, 1985.

\begin{tabular}{lcr}
\hline Country/region & Public & Private \\
\hline United States & 45.1 & 54.9 \\
Canada & 94.2 & 5.8 \\
Nordic & 26.0 & 74.0 \\
Europe $^{a}$ & 62.6 & 37.4 \\
Japan $_{\text {New Zealand }}$ & 41.7 & 58.3 \\
Australia $^{\text {Temperate }}$ & 74.3 & 25.7 \\
Tropical $^{\mathrm{C}}$ & 73.7 & 26.3 \\
& 56.0 & 44.0 \\
\hline
\end{tabular}

aExcluding the Nordic countries.

${ }^{b}$ Average for developed countries (UN-ECE 1992).

'Countries in tropical regions of Africa. Asia, and Latin America; although ownership status of forests is frequently unclear, public ownership, including communal forests, is predominant (Lanly 1982).

Source: UN-ECE (1992, 1985), Lanly (1982).

countries have relatively higher proportions of private ownership than other developed countries. Ownership patterns affect the mix of forest outputs, and the type and stability of management practices. Although public ownership is typically thought to best assure provision of non-market goods and intangible forest benefits, private management is recognized as efficiently providing commodity-based forest outputs.

\section{Plantation Forests}

Plantations represent an important component of industrial timber production in the temperate zone, and are a source of both industrial timber and nonindustrial products in the tropical zone. However, estimating the area of forest plantations presents some challenges. The term "plantation" has varied meanings, and even where a precise definition is available, it is not universally applicable. For example, in the tropical zone forest resource assessment, plantations are defined as forests established artificially, either on land that previously was not forested, or in which the species composition was changed (FAO 1992). For temperate zone countries, however, this definition is probably too restrictive; the term plantation is commonly used to mean forests established using artificial regeneration, in some cases using genetically-improved planting stock. Management of plantation forests is generally more intensive than natural forest (shorter rotations, for example); the number of species is reduced, often to a single species, and the forest is structurally and biologically less complex than natural forest of the same region. 
Table 8.-Estimated area of plantation forests, by country or region, and ecological zone, 1990.

\begin{tabular}{lcc}
\hline $\begin{array}{l}\text { Country or } \\
\text { region }\end{array}$ & Plantation area & $\begin{array}{c}\text { Share of } \\
\text { total forest }\end{array}$ \\
\hline & million hectares & percent \\
World & 127.7 & 3.2 \\
Temperate zone & 97.0 & 4.2 \\
Of which & 13.4 & 4.5 \\
United States & 1.5 & 0.3 \\
Canada & 33.0 & 2.9 \\
Europe and C.I.S. & 10.2 & 40.5 \\
Japan & $30.0^{\mathrm{b}}$ & 24.0 \\
China & 3.3 & 38.8 \\
Other temperate Asiac & 5.6 & 2.9 \\
Southern Hemisphere & & 1.8 \\
Tropical zone & 30.7 & 8.2 \\
Of which & & 0.3 \\
Asia and Pacific & 22.6 & 0.7 \\
Africa & 2.1 & \\
Latin America & 6.0 & \\
\end{tabular}

aEurope (including the Nordic countries) and the Commonwealth of Independent States.

'Estimates of plantations in China vary widely. Mather (190) reports a range of 17.5 to 28.0 million hectares; FAO (1988) reports 12.7 million hectares. The figure used here is the one reported by Sedjo (1987).

"Korea and Taiwan.

'Australia, New Zealand, Chile, Argentina, and South Africa; plantations of exotic species are 16 percent of the forest area in both New Zealand and Chile.

'Data reported by FAO (1992b); area planted is adjusted for estimated survival rate (70\%).

Sources: based on data reported in FAO (1992b), FAO (1988), UN-ECE (1992), and Mather (1990).

Table 8 shows estimates of the area in forest plantations in 1990, by country or region and ecological zone; the share of total forest in plantations also is shown. Data for the tropical zone are based on figures reported by FAO (1992); data for the temperate zone are estimates based, in part, on data reported by UN-ECE (1992). Because the definition of plantation is somewhat vague, especially for temperate zone forests, these data for 1990 must be considered indicative rather than definitive. In most cases, data in table 8 are based on data reported for 1975 by Sedjo (1987), or data for 1985 reported by Mather (1990), revised to account for expansion of plantation area in subsequent years. The figure of 127.7 million hectares is a little more than $3 \%$ of world forest area, and represents a $40 \%$ increase in world plantation area in the past 15 years. Sedjo (1987) reports plantation area in 1975 at 90 million hectares, composed of 82 million hectares in temperate, developed countries, and about 8 million hectares in developing countries (mostly tropical). Temperate zone plantations are estimated to have increased by slightly less than $20 \%$ since 1975 ; the area of plantations in tropical countries is estimated to have increased by nearly $300 \%$ in the same period. For comparison, between 1977 and 1990, the area of pine plantations in the U.S. South increased by nearly $60 \%$ (USDA Forest Service 1988); these plantations account for about $75 \%$ of the plantation area estimated for the United States in 1990. Plantations are estimated to account for about $5 \%$ of the forest area of the United States, slightly more than the average for all temperate zone countries.

Temperate zone plantations are predominantly coniferous species; most are managed for industrial wood products; and most are the consequence of reforestation rather than afforestation. That is, these plantations generally do not expand existing forest area. Afforestation of idle crop or grazing land (in the United States and United Kingdom, for example) is an exception. Native species account for most of the plantation area in most Northern Hemisphere, temperate zone countries. Growth rates may be somewhat higher than growth rates for natural forest, as a result of the use of improved planting stock, or more intensive management practices.

In the temperate zone of the Southern Hemisphere, most plantations are fast-growing, exotic species, with a shorter production cycle than native species. In the past decade, production from exotic softwood plantations in New Zealand, Chile, and Australia has increased significantly; these plantations now account for about $3 \%$ of world coniferous industrial roundwood productionmore than three times their share of coniferous forest area. By the year 2020, however, harvests from existing softwood plantations in the Southern Hemisphere may be as much as four times current harvest.

Three countries-India, Indonesia, and Brazil-account for $80 \%$ of plantations in the tropical zone. Plantations in India account for more than $40 \%$ of the tropical plantation area shown in table 8 , and more than $50 \%$ of the plantation area reported for the Asia and Pacific region (FAO 1992). Indonesia accounts for about $20 \%$ of all tropical zone plantations; Brazil accounts for about $16 \%$ of the total (FAO 1992). Most of the plantations in the tropical zone are classified as nonindustrial, ${ }^{5}$ these include plantations for erosion control, for example, and agroforestry plantations-joint production of trees and agricultural crops (FAO 1992). In the past decade, the area of nonindustrial plantations in the tropical zone increased faster than the area of plantations established for production of industrial timber products. In both

${ }^{5}$ This term refers to management objectives, not ownership of plantations. 
Asia and Latin America, Eucalyptus sp. are the dominant species planted in industrial plantations, accounting for more than one-half of the area; pines (Pinus sp.) and teak (Tectona grandis), the latter mostly in Asia, account for most of the remaining industrial plantations(FAO1992). In addition to industrial and nonindustrial forest plantations, some tree plantations established for annual crop production in the tropical zone have contributed to the supply of wood and wood products. Data for these "non-forestry plantations" (rubber, coconut, and oil palm) are not shown in table 8. These plantationsoccupy about 14 million hectares in tropical Asia, and an additional 2 million hectares in Africa and Latin America (FAO 1992).

\section{Patterns and Trends in Forest Use}

Patterns of forest use are broadly determined by the extent and type of forest cover, by the nature and scale of economic development, and by social values, institutions, and processes. Ideally, data should allow us to quantify and value, on a comparable basis, the full range of goods produced from forests-both timber and nontimber commodities; we also should have a basis for

\section{Table 9.-Goods and services from forests.'}

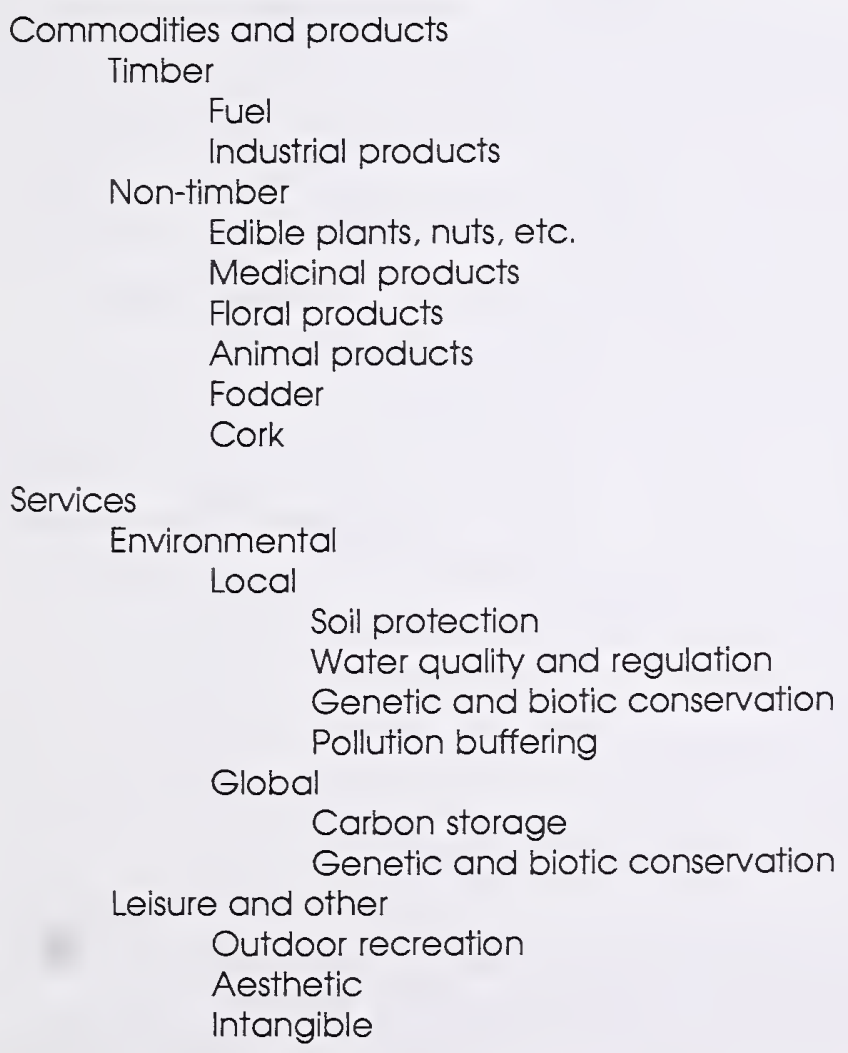

'Following the classification framework used by United Nations (1992) these are "use" values, both direct and indirect; non-use values such as existence value, or valuing forests for future generations could also be considered. estimating the value placed on services provided by forests (table 9). These services include environmental functions, such as carbon sequestration, pollution buffering, and maintaining reserves for diverse flora and fauna, as well as services such as outdoor recreation and amenity benefits. For the most part, this remains an ideal. We can quantify well the use of timber as an industrial commodity; data on the use of forests for fuel-which accounts for more than one-half of world timber production (FAO 1992a) - are less reliable. However, we lack systematic, reliable data to quantify use and extraction of non-timber commodities, and to estimate values placed on all types of services from forests (UN 1992). We also lack a conceptual framework within which a comprehensive approach to forest value can be organized. Our ability to quantify the magnitude and value of industrial timber products should not overwhelm our recognition of other benefits and values produced by forests. Therefore, after a summary of world timber production data, other forest values will be briefly addressed.

\section{Timber}

Worldwide, timber is the most important commodity removed from forests (World Resources Institute 1991). The importance of timber is reflected in its value in local, regional, and international markets, as well as in terms of the impact of its removal on forests. Fuelwood is the most important timber product, worldwide, accounting for more than one-half of world timber harvest (table 10). Fuelwood accounts for as much as $90 \%$ of timber production in developing countries; even in developing countries that produce and export large volumes of industrial timber products, such as Indonesia, fuelwood accounts for more than $80 \%$ of timber harvested. Wood provides domestic heating and cooking needs for nearly one-half of the world's population (United Nations 1992). Information on the economic value of fuelwood is limited; markets are typically local or regional, and less formal than markets for industrial timber and products. Using a replacement cost approach, the value of wood for fuel can be estimated at to be at least $\$ 75$ billion. For example, United Nations (1992) estimated the value of the projected fuelwood deficit for developing countries in the year 2000 at more than $\$ 30$ billion. The scarcity of substitutes for wood fuel, and the inability to afford them when they are available, increases the importance of this commodity in developing country communities and economies. 
Table 10.-World and United States production of timber and timber products, 1990.

\begin{tabular}{|c|c|c|}
\hline Timber or product group & World & United States \\
\hline & \multicolumn{2}{|c|}{ million cubic meters } \\
\hline Fuelwood & 1.796 .2 & 85.9 \\
\hline $\begin{array}{l}\text { Industrial roundwood } \\
\text { Of which }\end{array}$ & $1,654.2$ & 415.1 \\
\hline $\begin{array}{l}\text { coniferous } \\
\text { nonconiferous }\end{array}$ & $\begin{array}{r}1,138.2 \\
516.0\end{array}$ & $\begin{array}{r}315.2 \\
99.9\end{array}$ \\
\hline $\begin{array}{l}\text { Sawn wood } \\
\text { Of which }\end{array}$ & $485.9^{b}$ & 103.9 \\
\hline $\begin{array}{l}\text { coniferous } \\
\text { nonconiferous }\end{array}$ & $\begin{array}{l}361.4 \\
121.6\end{array}$ & $\begin{array}{l}86.4 \\
17.3\end{array}$ \\
\hline $\begin{array}{l}\text { Wood-based panels } \\
\text { Of which }\end{array}$ & 124.9 & 32.1 \\
\hline $\begin{array}{l}\text { veneer } \\
\text { plywood } \\
\text { particleboard } \\
\text { fiberboard }\end{array}$ & $\begin{array}{r}4.9 \\
49.7 \\
52.4 \\
18.0\end{array}$ & $\begin{array}{l}\text { na } \\
18.8 \\
8.6 \\
4.7\end{array}$ \\
\hline fiberboard & \multicolumn{2}{|c|}{ million metric tons } \\
\hline $\begin{array}{l}\text { Paper and paperboard } \\
\text { Of which }\end{array}$ & 238.2 & 72.0 \\
\hline newsprint & 33.1 & 6.0 \\
\hline printing and writing paper & 68.1 & 20.1 \\
\hline household and sanitary paper & 12.5 & 5.3 \\
\hline wrapping and packaging paper & 90.1 & 36.9 \\
\hline other paper and paperboard & 34.5 & 3.7 \\
\hline
\end{tabular}

a Product basis.

"Includes "sleepers" that are not classified by coniferous and nonconiferous.

Source: Food and Agriculture Organization (1992a)

Table 10 also summarizes world production of industrial timber and timber products. Data for the United States are shown for comparison. Nearly $70 \%$ of the world's timber harvest for industrial products is coniferous species. Sawn wood, most of which is used in construction, directly accounts for about one-half of the harvest of industrial timber. However, a significant proportion of residues from production of sawn wood is used in production of wood-based panels (particleboard and fiberboard) and in production of pulp for paper and board production. Recovered paper accounts for more than $30 \%$ of the raw material for pulpand paper production; residues from the production of sawn wood and plywood account for about $20 \%$ of raw material for pulp and paper.

Table 11 displays world timber harvest by economic groupings and type of utilization; table 12 shows similar data, but focuses on the distribution of use by ecological zones (boreal, temperate, and tropical). These data clearly show the relationship between economic develop- ment, forest type, and pattern of forest use. Developed countries, located in the temperate zone, with a large component of coniferous forests, harvest primarily coniferous species (70\% of total harvest) and use nearly all of the timber harvested for industrial purposes $(83 \%$ of total harvest). Developing countries, located for the most part in the tropical zone, have predominantly nonconiferous forests, harvest nonconiferous species ( $80 \%$ of total harvest), and use this timber primarily for fuel ( $80 \%$ of the harvest).

Table 11.-World timber harvest by economic group and species group, 1989.

1 la.-Total roundwood production (million cubic meters).

\begin{tabular}{lccc}
\hline $\begin{array}{l}\text { Economic } \\
\text { group }\end{array}$ & Coniferous & Nonconiferous & Totala \\
\hline & 1,098 & 436 & 1,534 \\
Developed & 257 & 1,665 & 1,922 \\
Developing & 1,355 & 2,101 & 3,456 \\
World &
\end{tabular}

a Roundwood used for charcoal production is included in the nonconiferous category.

11b.-Industrial roundwood production (million cubic meters).

\begin{tabular}{lccr}
\hline $\begin{array}{l}\text { Economic } \\
\text { group }\end{array}$ & Coniferous & Nonconiferous & Total \\
\hline & & & \\
Developed & 1,007 & 258 & 1,265 \\
Developing & 127 & 267 & 394 \\
World & 1,134 & 525 & 1,659
\end{tabular}

11c.-Production, net trade, and per capita consumption of timber.

\begin{tabular}{lccccc}
\hline $\begin{array}{l}\text { Economic } \\
\text { group }\end{array}$ & $\begin{array}{c}\text { Pro- } \\
\text { duction }\end{array}$ & $\begin{array}{c}\text { Net } \\
\text { trade }\end{array}$ & $\begin{array}{c}\text { Con- } \\
\text { sumption }\end{array}$ & $\begin{array}{c}\text { Popu- } \\
\text { lation }\end{array}$ & $\begin{array}{c}\text { Per capita } \\
\text { con- } \\
\text { sumption }\end{array}$ \\
\hline million $m^{3}$ & & millions & $\mathrm{m}^{3}$ \\
$\begin{array}{l}\text { Developed } \\
\text { Of which } \\
\text { United States }\end{array}$ & 1,534 & 9 & 1,525 & 1,265 & 1.2 \\
$\begin{array}{l}\text { Developing } \\
\text { World }\end{array}$ & 1,922 & -55 & 588 & 249 & 2.4 \\
\hline
\end{tabular}

Total production, including fuelwood.

bTrade in industrial products converted to roundwood equivalent; negative sign indicates net imports.

Note: columns and rows may not add to total because of rounding.

Source: estimated from data reported by FAO (1992a). 
Table 12.-World timber production and forest products trade by forest zone and species group, 1989.

\begin{tabular}{|c|c|c|c|c|}
\hline & \multicolumn{3}{|c|}{ Forest zone } & \multirow[b]{2}{*}{ Total } \\
\hline & Boreal & Temperate & Tropical & \\
\hline \multicolumn{5}{|c|}{ Roundwood production (million cubic meters) } \\
\hline $\begin{array}{l}\text { Total } \\
\text { Of which } \\
\text { coniferous } \\
\text { nonconiferous }\end{array}$ & $\begin{array}{l}673 \\
570 \\
103\end{array}$ & $\begin{array}{l}680 \\
497\end{array}$ & $\begin{array}{r}105 \\
1,501\end{array}$ & $\begin{array}{l}3,456 \\
1,355 \\
2,101\end{array}$ \\
\hline \multicolumn{5}{|c|}{ Industrial roundwood production (million cubic meters) } \\
\hline $\begin{array}{l}\text { Total } \\
\text { Of which } \\
\text { coniferous } \\
\text { noconiferous }\end{array}$ & $\begin{array}{r}573 \\
514 \\
59\end{array}$ & $\begin{array}{l}566 \\
235\end{array}$ & $\begin{array}{r}54 \\
231\end{array}$ & $\begin{array}{r}1,134 \\
525\end{array}$ \\
\hline \multicolumn{5}{|c|}{ Forest products trade (million USS) } \\
\hline $\begin{array}{l}\text { Imports } \\
\text { Exports } \\
\text { Trade balance }\end{array}$ & $\begin{array}{r}5,098 \\
40,961 \\
35,863\end{array}$ & $\begin{array}{r}83,590 \\
43,322 \\
(40,268)\end{array}$ & $\begin{array}{r}6,105 \\
10,510 \\
4,405\end{array}$ & $\begin{array}{l}94.793 \\
94.793\end{array}$ \\
\hline
\end{tabular}

Sources: Estimated from data reported by FAO (1992a), Allen and Lanly (1991), FAO(1992b), and UN-ECE (1992).

Patterns of timber production and use have changed in the past 40 years. World timber production has increased at a rate slightly faster than the increase in population growth; but unlike population growth, timber production and consumption shows significant cyclesin response to economicactivity. The share of timber used for industrial products has increased, but remains less than one-half of the total harvest. Perhaps the most significant trend over 40 years has been the increase in the share of timber harvested in developing countries that is used for industrial products. Although still quite low (averaging about 20\%), this use of timber accounted for only $5 \%$ of the harvest in developing countries in 1950 (Pringle 1976).

The most dramatic comparison of global patterns of timber consumption is in table 11c. Developed countries consume timber at a per capita rate nearly three times that of developing countries; the United States consumes timber at a rate nearly double the developed country average. Although developed countries as a group produce more timber than they consume, the United States and Japan are exceptions; both countries are net importers of forest products. The largest forest products trade flows are among developed countries in the Northern Hemisphere. Exports from boreal countries (Canada, the Nordic countries, and Russia) are to other temperate zone countries (table 12).

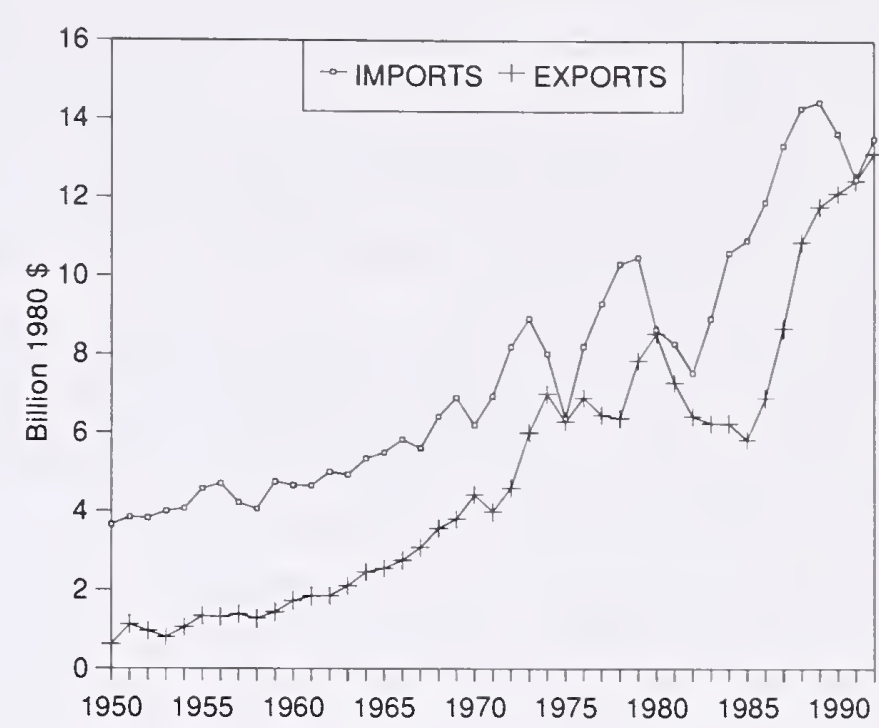

Figure 1.-United States forest products trade, 1950-1992.

Developing countries, as a whole, are netimporters of timber; net exports of logs and semi-processed products (such as sawn wood) are more than offset by imports of pulp and paper products. The tropical developing countries - with a relatively greater endowment of forestsare net exporters of timber products, however (table 12). Timber and timber products account for a significant share of export earnings and economic development for these countries. Tropical countries accounted for $\$ 11$ billion of forest products exports in 1989, about $11 \%$ of world forest products exports; imports, mostly from developed countries totalled more than $\$ 6$ billion. Trade among developed countries has continued to grow, as has domestic consumption of industrial forest products. The composition of forest products exports from tropical countries is rapidly moving away from logs and semi-processed commodities toward processed products, such as lumber and veneer-based panels, and secondary manufactures, such as furniture.

United States forest products trade.-The United States is the world's leading importer of forest products, and is second only to Canada as an exporter of forest products. Since 1950, U.S. trade in forest products has expanded significantly. In 1992, U.S. imports of forest products were \$17.6 billion, up from \$1.1 billion in 1950 . Adjusted for inflation, imports increased at an average annual rate of more than 3\% over the period 1950-1992. As with all merchandise imports, imports of forest products reflect the timing of the U.S. business cycle (fig. 1).

Imports of forest products from Canada account for nearly $75 \%$ of all U.S. forest products imports; and softwood lumber, pulp, and newsprint account for 
three-fourths of the value of this trade. Pulp and paper products account for two-thirds of U.S. imports from all sources. United States consumption and imports of forest products depend largely on temperate zone forests; products manufactured from softwood species from North America make up the bulk of U.S. forest products consumption.

Over the past 40 years, U.S. exports of forest products grew more rapidly than imports, increasing to $\$ 17.1$ billion in 1992 from $\$ 190$ million in 1950. Adjusted for inflation, exports increased at an annual rate of nearly $8 \%$ over the period $1950-92$. The most rapid, sustained expansion of exports has taken place in the recent past (1985-92) (fig. 1). This increase in U.S. forest products exports is largely attributable to the devaluation of the U.S. dollar in 1985; export promotion and efforts to have trade barriers reduced or removed also have contributed to the growth in U.S. exports. Shipments to three countries-Japan, Canada, and Mexico-account for one-half of all U.S. forest products exports. As with U.S. imports, trade with temperate countries accounts for most forest products exports; trade with tropical countries accounts for a somewhat larger share of exports than of imports, however. Exports to tropical countries (including Mexico) account for $18 \%$ of U.S. forest products exports.

Pulp and paper products dominate in U.S. forest products exports, accounting for $60 \%$ of the value U.S. exports to all destinations. Wood pulp, paper and paper products, and paperboard each account for about $20 \%$ of the value of U.S. forest products exports; softwood logs account for about $10 \%$ of the value; and softwood lumber accounts for about $8 \%$ of the value U.S. exports.

Balanced forest products trade is characteristic of U.S. recessions, and typically results from a sharp reduction in imports combined with increased exports (fig. 1). The expansion of U.S. exports that began in 1985, combined with a recession in the U.S. economy 1990-91 all but eliminated the forest products trade deficit in 1991. Despite continued growth in the value of exports, increasing imports resulted in a return to a deficit account in forest products trade (fig. 1).

Unlike Japan, where tropical timber accounts for as much as $15 \%$ of forest products consumption, tropical timber accounts for a very small share of U.S. imports and consumption of forest products. However, tropical timber accounts for a significant share of imports of specific commodity groups. Tropical plywood accounts for about $80 \%$ of all plywood imports, and more than $90 \%$ of U.S. imports of hardwood plywood; tropical

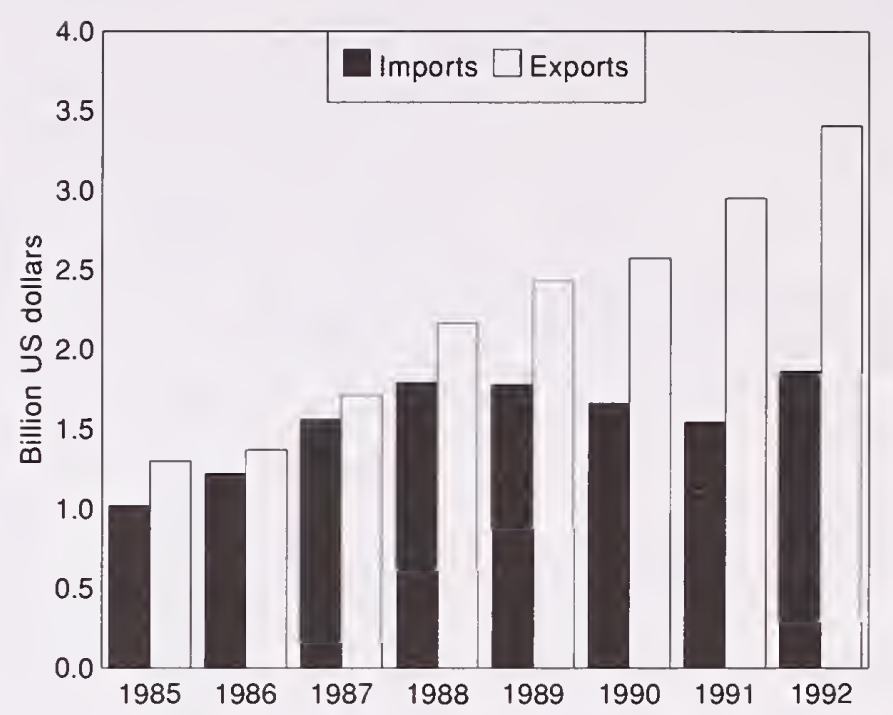

Figure 2.-United States forest products trade with tropical countries, 1985-1992.

lumber accounts for one-half of U.S. imports of hardwood lumber. Three tropical countries-Indonesia, Mexico, and Brazil-are among the top fivesuppliers of forest products to the United States (based on the total value of trade); nevertheless forest products imports from all tropical countries account for only $11 \%$ of total U.S. imports of forest products.

Figure 2 summarizes recent trends in U.S. forest products trade with tropical countries. The United States is a net exporter of forest products to tropical countries; over the period 1985-92, the value of net trade in forest products with tropical countries increased to $\$ 1.5$ billion from $\$ 300$ million. U.S. exports to tropical countries nearly tripled between 1985 and 1992, while U.S. imports from tropical countries peaked in 1988, declined 1989-1991, and increased in 1992. Shipments to Mexico account for nearly one-half of U.S exports to tropical countries.

Pulp and paper products comprise the majority of U.S. exports to tropical countries, and produce a trade surplus of $\$ 2$ billion. In 1991 and 1992, nearly $80 \%$ of the value of forest products exports to tropical countries was accounted for by pulp and paper. Packaging paper and board, pulp, and miscellaneous paper manufactures (in decreasing order of importance) account for most U.S. pulp and paper exports to these countries. In contrast, solid wood products comprise the bulk of U.S. imports from tropical countries. Plywood is the single most important commodity group. Net imports of solid wood products from tropical countries were valued at \$600 million, in 1992.

Imports of logs, and sawn wood, veneer, and plywood manufactured from tropical timber were valued 
at $\$ 807$ million, in 1992. These commodities account for less than $5 \%$ of U.S. forest product imports, and about $10 \%$ of U.S. imports of solid wood products. U.S. imports of value-added manufactured forest products such as window and door parts have grown faster than imports of "traditional" tropical timber products (logs, lumber, veneer, and plywood); more than one-half the value of U.S. forest products imports from tropical countries is accounted for by value-added products and pulp and paper products. In addition, in 1992, the United States imported wooden furniture valued at nearly $\$ 500$ million from tropical countries-20\% of the value of all wooden furniture imported by the United States. Imports from non-tropical countries (in both Asia and Europe) account for nearly $20 \%$ of the value of U.S. imports of lumber, veneer, and plywood.

\section{Non-łimber Forest Products}

Temperate and tropical forests are the source of a variety of animal and plant products other than timber for industrial products and fuel; these include animals, plants, nuts, and fruits. Some of these products enter regional, national, or even international markets; however, many products are consumed locally, often without passing through any organized markets. As a result, information on the value or even the quantity of nontimber products of forests is extremely limited; often, value is understood only in the case of scarcity (Wickens 1991). Nevertheless, knowledge of the importance of these products is required to fully understand the social and economic contributions of forests in developing and developed countries. An emphasis on non-timber commodities has been suggested as a characteristic of sustainable management of tropical forest, because removal of the forest structure (trees) is not always required. However, the extraction and use of non-timber commodities may appear more environmentally benign simply because the scale and intensity of use is typically low. Where intensity of use increases, direct and indirect impacts on forest ecosystems are likely to increase. It is also important to keep in mind that users of non-timber products are, in many cases, different from the users of timber. These differences can be the source of considerable conflict over rights of forest use and the beneficiaries of forest management, either on public or private forest land.

The potential importance of non-timber forest products can be illustrated by examples from temperate and tropical regions. Floral greens harvested from the forests of the coastal Pacific Northwest of the United States and Canada were estimated to have been valued at nearly $\$ 130$ million in 1989; harvesting and processing employed 10,000 people in seasonal and permanent positions (Schlosser and others 1991). Commercial and recreational harvest of edible wild mushrooms in the same region is valued in the millions of dollars. Although small in comparison to the industrial forest economy of the region, these non-timber products occupy important social and economic niches. For example, employment in the floral products industry provides important contributions in terms of the timing (seasonality) and location in rural communities (Schlosser and others 1991). Food and non-food products from the forests of Europe also are important; although data are generally lacking, none are of national economic importance(UNECE 1992b). An exception is cork production in Portugal; cork production accounts for about one-fourth of employment in the forest industries, and exports of cork were valued at more than $\$ 550$ million in 1991 .

Non-timber forest products make significant contributions to economic activity, including export trade in a number of developing countries. The value of international trade in non-timber forest products from Southeast Asia is estimated to be in the billions of dollars (DeBeer and McDermott 1989). Non-timber forest products account for about $6 \%$ of all forest products exports from Indonesia, including timber. For Indonesia, Malaysia, Thailand, and the Philippines, rattan dominates in the value of non-timber forest products exports; as is the case with timber, these countries are making an effort to shift from exports of raw material to exports of products—mainly furniture (Laarman and Sedjo (1992). Taking into account the fact that most non-timber products are not traded, and do not enter markets, the social and economic value can be seen to be substantial.

\section{Services}

Services from forests include both environmental services, such as watershed services (slope stability and water yield regulation), climate regulation, and other services (table 9). Forests play a critical role in environmental processes, such as the hydrologic and climate cycles, protecting soil from erosion, maintaining a reservoir of plant and animal genetic material, and absorbing and buffering pollution discharges. Although provision of these services has always been a characteristic of forests, attention paid to the importance of forests in these processes has grown in recent decades, as regional 
and global systems have been stressed. Kramer and others (1992) and Panayotou and Ashton (1992) provided a more extensive list of services, and examples of the value of these services from forests.

Howlett and Sargent (1991) and Sampson and Hair (1992) compiled an extensive literature on the effects of forests on global climate, as well as the possible effects of climate change on forests. Recognition of these "environmental" services of forests is not new (Marsh 1884); but it is considerably more sophisticated. Nevertheless, definitive results demonstrating, for example, the contribution of forests to atmospheric carbon-from deforestation, timber harvesting, and natural disturbances, such as fire, insects, and disease-are lacking. In addition to a better understanding of the role of forests as either source or sink of carbon, we also lack an understanding of the possible role of forests in the context of a broader, more comprehensive approach to managing humanimpactson globalenvironmental systems. Equally important is the question of whether these services of forests conflict with or complement other forest management objectives.

The role of forests in supporting or providing human leisure and recreation services also is not new. The value of recreation services ("ecotourism") supported by forests, among other natural assets, is receiving increasing attention in the management of tropical as well as temperate forests. In the late 1980s, tourism was the second-largest industry in the world, and as much as one-half of world tourism is nature-based (Whelan 1991). Tourism is estimated to have accounted for more than $\$ 55$ billion in revenue for developing countries (Whelan 1991); even if only a portion of this revenue is attributable to forests, this is significantly greater than revenues from export of industrial timber products. However, the type of employment, distribution of income, and patterns of social impacts also differ significantly. As is the case with non-timber commodities, users and beneficiaries of tourism and other forest services differ from users and beneficiaries of commodity outputs.

\section{Comparing U.S. and Global Conditions}

Table 13 summarizes selected data for U.S. forests and compares them to world data to provide a starting point for considering U.S. forests in a global context. More important, data such as these begin to form the basis for measuring U.S. "performance" relative to other
Table 13.- Selected forest data for the United States, with comparisons to world data.

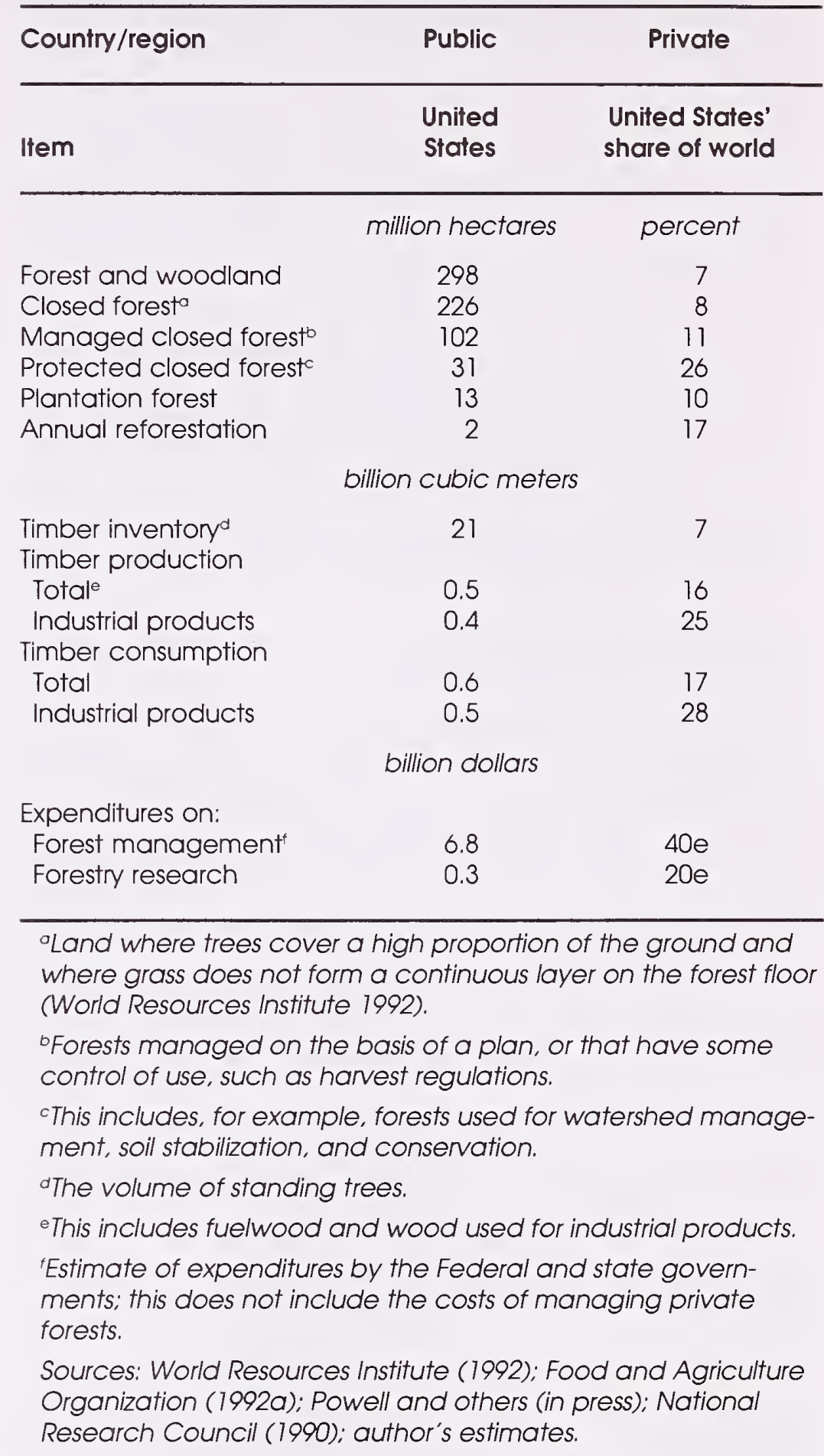

countries. One context for such comparisons is the UNCED forestry principles that, in broad terms, have the objective of promoting the "conservation and rational utilization of forests."

To European settlers of the 17th and 18th centuries, one of the most striking features of North America was the extensive forests covering more than 400 million hectares ( 1 billion acres) of what was to become the United States. One-half of the country was forested. Today, the United States has nearly 300 million hectares (737 million acres) of forest, over $30 \%$ of its land area; this amounts to about $7 \%$ of world forests. The United States has about $13 \%$ of the world's temperate forests, and 
nearly one-half of the world's coastal temperate rain forest (Ecotrust 1992). By the simple measure of forest area per capita the United States, with only $5 \%$ of world population, is relatively well-endowed with forests capable of providing a wide array of commodity and noncommodity benefits. However, little of the forest that existed in the 17th century remains; less than $10 \%$ of the U.S. forest area is undisturbed by recent human use or management (Szaro 1992).

Morethan one-half of U.S forests are privately owned, reflecting an important aspect of the U.S. approach to forest management. The United States accounts for about $40 \%$ of the world's private forests. Reliance on privately owned and managed forests is greater only in the Nordic countries-where the relative importance of the forest sector in national economies is considerably higher as well. Private ownership of forests is very small in Canada, although some public forests are privately managed on a long-term basis. About one-half of the area of European forests, and 20\% or less of the forest area of tropical countries is privately owned.

Relative to the rest of the world, a higher proportion of U.S. forests, both public and private, are managed; "managed" refers to some degree of control over forest use (World Resources Institute 1992). One-half of the closed forest area of the United States is managed; world-wide, one-third of closed forests are managed (World Resources Institute 1992). Nearly all of theclosed forests of Europe are managed. The United States also reserves from exploitation a significant portion of its forests; about $10 \%$ are removed from timber production to provide other services, such as conservation or recreation. The United States accounts for about one-quarter of world forests in this category, and accounts for nearly one-half of protected, closed forests in the temperate zone (World Resources Institute 1992).

In the decade 1977-1987, the forest area of the United States declined by about 4 million hectares, slightly more than $1 \%$. Someland was removed from agricultural production and reforested; but, this did not offset conversion of forests to urban uses. Until recently, loss of another 7 million hectares of forest was expected over the next two decades, with nearly all forest conversion to uses other than agriculture, primarily to support urban development (USDA Forest Service 1989). However, more recent data indicate a reversal of the declining forest area trend that began in the 1960s; between 1987 and 1992, forest area of the United States is estimated to have increased by about 200 thousand hectares (Powell and others, in press).
Over the period 1963-1987, the decline in forest area in the United States was quite small compared to total world deforestation. The total loss in forest area over this period was about 12 million hectares ( 30 million acres), a decline of about $4 \%$ in nearly 25 years (Powell and others, in press). Until the late 1980s, the United States accounted for about $1 \%$ of the net loss in world forest area. The decline in U.S forest area contrasted sharply with trends in other developed, temperate zone countries. Over the past four decades, forest area increased in Europe (especially France, Germany, and the United Kingdom), and in Japan. However, the expansion of forests in Japan and Europe from 1950-1990 reflected an effort to reverse sharp declines in forest area in the period 1900-1950.

Globally, timber remains the primary product removed from forests (World Resources Institute 1992). TheU.S. share of world timber inventory is proportional to its share of world forest area; but, the U.S. share of timber production is significantly higher. The United States produces one-fourth of the industrial timber harvested in the world, and sustains high rates of timber production across diverse forest types, at a scale greater than any other country, and in support of diverse forest industries. Sustained production on a national basis has depended, in part, on the ability of timber using industries to shift among regions within the United States. Nevertheless, measured in terms of volume harvested per hectare of exploitable forest, U.S. rates of production are equalled in some European countries, but are exceeded in few. Of the top 20 countries producing industrial timber, only Austria and Germany have production intensities (measured in cubic meters per hectare) that are significantly higher than the United States. Timber production intensity in the United States and, by inference, timbermanagement intensity, is roughly equal to that in theNordic countries ( 2 cubic meters per hectare of closed forest).

U.S. accomplishments in managing forests and producing forest products are exceeded only by its consumption of forest products. On a per capita basis, the United States consumes timber at more than double the average for developed countries, more than four times the world average, and five times the average for developing countries (table 10). The United States consumes nearly $30 \%$ of the world's production of industrial timber and is both a net importer, and the world's leading importer of forest products. At the same time, however, the United States also is one of the leading exporters of forest products. 
Relatively high rates of timber consumption in the United States reflect high levels of wealth-measured in terms of dollar income and abundant forests-and patterns of social development. Like other heavily-forested, developed countries, and unlike many other developed and most developing countries, the United States consumes timber in place of other materials in a wide variety of uses. Lumber accounts for about one-half of U.S. consumption of industrial timber. Figure $3 \mathrm{com}-$ pares patterns of lumber consumption in the United States with two other developed countries and one developing country. Of the developed countries, only Japan uses a higher proportion of lumber for housing. China consumes much less lumber per capita, and uses a considerably smaller proportion of the lumber that is consumed in residential construction. Figure 3 does not reflect relative patterns of use of all materials; for example, compared to most temperate, developed countries, the United States consumed relatively more timber, but relatively less concrete, steel, and other materials in housing. Patterns of use of wood-based panel products display even greater differences between the United States and other countries.

Figure 4 compares another component of U.S. forest products consumption: sources of fiber for paper and board products. The United States relies on virgin fiber to supply about $45 \%$ of the raw material used for paper and board manufacturing; residues from lumber and plywood manufacturing supply about $30 \%$ of the raw material. Recovered wasteaccounts for about one-fourth of the raw material consumed, slightly more than Europe (and considerably more than Canada), but considerably less than Japan, Korea, and China. Recovery of

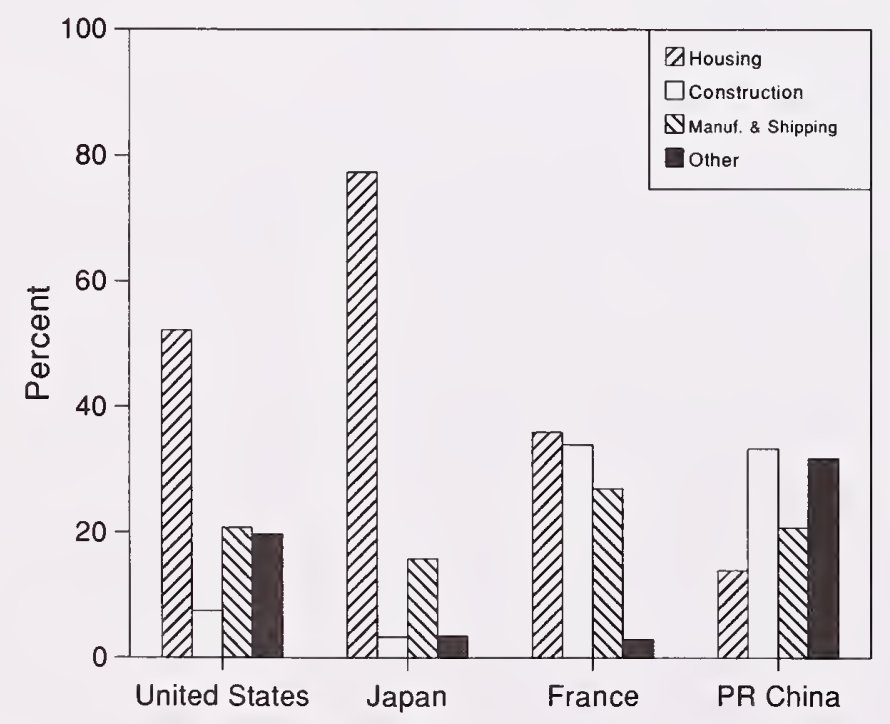

Figure 3.-End-uses of sawn wood in selected countries.
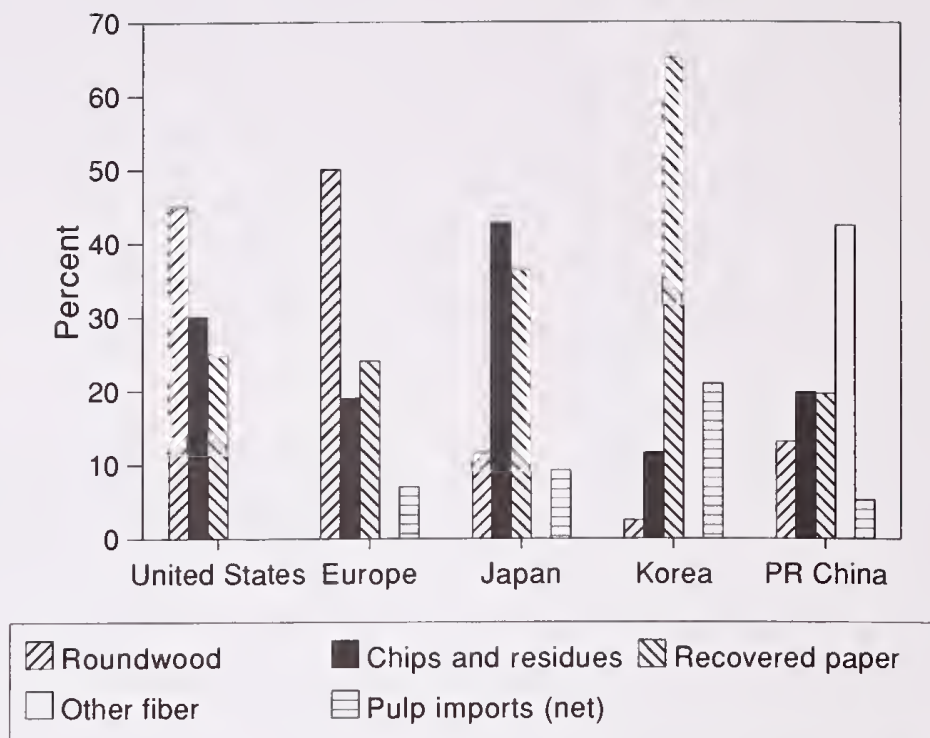

Figure 4. - Sources of fiber for paper and board production, selected countries or regions, 1990.

waste paper is greater than consumption; the U.S. exports waste paper and board to Pacific Rim markets.

Finally, table 13 shows U.S. public spending on natural resource management, including forest management and protection. Annual federal and state expenditures are substantial, measured in billions of dollars. U.S. expenditures represent a significant proportion of world expenditures, perhaps as much as $40 \%$. These data do not include any estimates of costs of managing private forests. The U.S. share of forestry research expenditures, public and private, is about $20 \%$ of the world total (National Research Council 1990, 1991). Although these amounts and shares are substantial, U.S. expenditures are not the highest among developed countries in terms of share of Gross National Product, or expenditures per hectare of forest. In Canada and Sweden, for example, a higher proportion of total public expenditures is spent on forests; in France and the United Kingdom, estimated spending per hectare of forest land exceeds that in the United States. However, total spending on forest management and conservation in the U.S. exceeds all spending in Canada and the European Community; total world spending is estimated at $\$ 17$ billion. And as significant as this expenditure is in scale, and its role in U.S. accomplishments in forest management and conservation, the estimated total cost of implementing the UNCED program for conservation and development of world forests is nearly double, at $\$ 32$ billion per year. ${ }^{6}$

'Agenda 21, Chapter 11, Combatting deforestation. Advance copy. Conches, Switzerland: United Nations Conference on Environment and Development, 14 June 1992; 22 p. 1. 


\section{Global Forestry Issues}

Global forestry issues can be broadly classified into two types of problems: problems that affect, and can only be resolved by the actions of more than one nation; and problems that can be resolved, in whole or part, by the actions of individual nations, but are shared by many nations. Truly global problems include issues such as global warming and mitigating the environmental impacts of commodity trade. Problems that are more universal than global include: identifying the role of forest resources in economic development and social change; sustaining ecological conditions and processes, and the production of commodities and services; and integrating land-use, industrial, and environmental policies to achieve multiple social objectives.

Thestriking differences in conditions illustrated when resource data are compiled by region, economic group, and ecological zone emphasize the importance of distinguishing global forestry issues and the forestry issues of individual countries and regions. For example, developed countries have industrial forest economies characterized by high rates of timber consumption per capita; timber consumed is predominantly industrial timber, primarily coniferous species from the temperate and boreal zones. Forests are managed relatively intensively for fiber production; but, non-commodity services of forests are increasingly demanded. In many countries, public ownership of forests is significant; and European and North American forest management has a long tradition of an active role for the public sector as a steward of forest resources and a supplier of timber to local and national markets. With a few exceptions, however, most developed countries rely, to a greater or lesser extent, on private ownership and management of forest resources to satisfy commodity and non-commodity objectives.

For nearly a century-and especially the past 50 years-assuring adequate supplies of wood fiber for industrial products was the central issue of forest policy for the developed countries. Although timber supply "crises," when they emerged, often were local, justification for public intervention in markets generally was based on the long period to maturity for forestry investments, and a perceived lack of adequate private investment. This role has never been a simple one, however, and has become considerably more complex as a result of a recognition of the non-timber commodity, and noncommodity benefits of forests. For the next century, forestry issues are likely to be significantly different as a result of changes in regional and global objectives for forests, changes in forest environments, and changes in patterns of production and consumption of timberbased products. In developed countries, predominant forestry policy issues for the future include:

1. Managing forests to maximize value measured across a broad range of goods and services;

2. Balancing production, and levels and patterns of timber consumption in a comprehensive, environmentally-sensitive materials policy;

3. Understanding the role of forests in mitigating the effects of global and regional ind ustrial pollution, and providing environmental services at the local, regional, national, and global scale; and

4. Understanding and addressing the global environmental impacts of commodity trade.

Significant changes from present policy issues include: (1) the recognition of public (and possibly private) benefits from forests that can be enhanced by management, but do not necessarily require extraction of commodities such as timber; (2) attention to patterns and levels of consumption as part of resource and environmental policy; (3) recognition of the opportunity-and need - to approach large scale, significantenvironmental problems by management of ecosystems, and recognition of the need to consider total environmental consequences of policies; and (4) increasing attention to the international consequences of domestic resource policies.

Many of these shifts in forest policy are made possible by social and economic structure of highly developed, industrialized economies in which there are substitutes for timber as a material, in which there is a reasonable prospect of re-employing labor displaced by reductions in commodity uses of forests, and in which consumer impacts of reductions in commodity production can be mitigated by technological developments (in production and consumption) and by the ability to import commodities. Many "global" forestry issues-such as the role of forests in climate change and the preservation of biological diversity-originate as concerns of the developed countries, and are given prominence on the international agenda.

For developing countries, forestry issues are inseparable from the fundamental challenges of development, and the environmental consequences of population 
growth, economic growth, and industrialization. Developing countries, in recognizing long-term, global environmental problems, face a challenge even greater than that of developed countries in trying to balance concern for environmental conditions with critical, shortterm, economic needs.

In developing countries, forestry issues include:

1. Identifying an appropriate and sustainable role for forest resources and commodity trade in a framework of policies that are consistent across sectors of the national economy;

2. Establishing a more equitable distribution of resources, a more stable set of property rights, and a system of incentives and rewards that begins to achieve broad-based social objectives;

3. Strengthening institutions for resource management, including both the public and the private sector; and

4. Understanding social, economic, and ecological factors that determine the extent to which the resource endowments of forested developing countries can be transformed into development assets consistent with management of local, regional, and global environmental systems.

These issues are not new or surprising. However, they are dominated by concerns that are typically outside the boundaries of forest and natural resource policy. Designing and implementing programs will require skills that are not typically acquired by natural resource management professionals. Although a better understanding of biological and technical issues is needed, the research and policy agenda must nevertheless focus on social and economic questions (Gregersen 1992).

In their fundamental role in the international economy, and as a result of their relative wealth and scale of resource consumption, the contribution of developed countries to the general problems of development, and the specific problems of forestry is critical. This was made clear in the process and products of UNCED. At the same time, nearly one-half of the world's forests, and more than $80 \%$ of the world's population are in developing countries. Any attempt to identify global forestry priorities based on democratic processes would shift the policy focus towards issues of sustenance and development and (perhaps) away from an emphasis on global environmental services. Ideally, these will not be conflicting objectives.
Although management of temperate forest ecosystems may be inherently easier than management of tropical ecosystems, the successes of temperate zone forest management are built on considerable experience, and a considerable, continuing investment in research and support of institutions for management. It is unreasonable to expect similar-or even more rapid-success in the management of tropical forest systems without the application of financial and technical resources. These resources must be applied in the collection of improved information on conditions and trends in global resources; building of public and private institutions-and human capital-necessary to support improved resource management; and in research necessary to identify technical opportunities for long-term management of tropical ecosystems that are consistent with social and economic systems in developing countries.

\section{Does U.S. Resource Policy Export Environmental Problems?}

Calculating global environmental impacts has been suggested as a practical and an ethical basis for U.S. resource policy (Bowyer 1992). If attention to domestic environmental impacts of production and consumption decisions is based on a genuine desire to minimize environmental impacts, impacts of U.S. policy actions on other countries also must be considered. Recent reductions in federal timber harvest (1990-1992) in the Pacific Northwest have been used as an example of resource policy requiring an analysis of international environmental impacts (Bowyer 1992; Schallau and Goetzl 1992). Substantial reductions in federal harvest are likely to have direct impacts in the Pacific Northwest; secondary impacts may be felt in regions that consume timber products produced in the PacificNorthwest; indirect impacts may occur in regions that compete directly with Pacific Northwest producers.

To argue that concern for international environmental impacts should influence domestic timber supply policies, one must conclude (1) that international environmental impacts of timber harvesting are significant; (2) that these impacts are greater than domestic environmental impacts and are attributable to U.S. policies; and (3) that other countries will not make environmentally acceptable choices in the management and use of their natural resources.

International environmental impacts.-There is some basis for the assertion that timber harvesting in tropical countries has significant environmental im- 
pacts, although the magnitude of these impacts varies widely and is disputed. In addition, activities other than production of industrial timber products are generally recognized as more significant factors contributing to severe environmental impacts such as tropical deforestation. Compared to the Pacific Northwest, timber harvesting in Siberia or the Russian Far East would require a larger area to produce a given volume of timber; however, even taking this into account, a smaller proportion of the total forest area would be affected by harvesting. The perception of the magnitude of impacts is related, in part, to the magnitude of benefits received in return. Impacts can be evaluated only with reference to a particular set of values and an understanding of the distribution—spatially, and over time—of positive and negative effects.

Comparison of environmental impacts.-It is difficult to compare environmental impacts of harvesting in the United States to impacts of harvesting in other countries-Siberia or Malaysia, for example. Components and processes in biological systems differ, and participants and values in social systems differ. Recognizing that a given level of consumption inevitably will have some environmental impacts does not provide a basis for choosing which of the possible impacts is preferred. If forced to engage in environmental "triage," how would we do it? Similar difficulties also are encountered when trying to compare environmental impacts of timber production and production of timber substitutes; the types of impacts are different, and no measurement exists to provide an absolute indicator of "better" or "worse." Value judgements inevitably are embedded in any analysis of this question, and answers depend, ultimately, on which types of impacts are socially more acceptable. In many cases, the acceptability of impacts is a matter of location; impacts spatially removed often are more tolerable than those nearby; impacts removed in time (delayed) also are more tolerable. To the extent this characterizes public response to environmental impacts of forest use, possible international impacts will be a weak basis for altering public resource policies.

International comparison of environmental choices.-Whether countries are capable of making informed choices regarding trade-offs between environment and industry is a sensitive question. Efforts to defineinternationally-applicable, absolute standards for judging environmental impacts, and trade-offs between industrial development and environmental conditions inevitably will result in conflicts over both social values and sover- eign rights. Whose standards and values should judge the severity of impacts? Should U.S. policy be concerned with any impacts, or only those impacts with global or transboundary consequences?

Domestic producers may find a competitive advantage in an argument that domestic production is more environmentally sensitive than production taking place in another country. Consumers are increasingly sensitive to production methods, at both the local and global scale. However, although anecdotal evidence of the importance in consumer preferences of issues such as "sustainably managed," "recycled content," or "organically grown," is substantial, there is, as yet, little systematic evidence to demonstrate the extent to which these factors actually affect consumer choice. Given that, the argument that impacts of domestic production may be relatively less significant than the environmental impacts of alternative sources of supply is a weak basis for changing public choice in domestic environmental policy. However, it is even more difficult to argue that the United States ought to maintain timber productionwith known environmental impacts-to both satisfy consumption in other countries, and avoid environmental impacts in other countries.

\section{Exporting U.S. Experience}

Looking at changes in conditions of U.S. forests over the past one hundred years, it is tempting and perhaps natural to consider offering the U.S. experience as a model for developing countries. In fact, the key elements of the Agenda 21 program for combatting deforestation ${ }^{7}$ are areas in which the United States can claim to have had success: sustaining multiple roles and functions of forests, sustainable management and conservation, promoting efficient utilization and assessment, and planning and periodic evaluation. However, before the United States can be offered as a model of forest management and conservation, we must examine U.S. forest conditions closely, and carefully consider how well U.S. experiences can be generalized and transferred.

First, the United States has considerable, but debatable accomplishments in forest management and conservation; U.S. conditions may be more ambiguous than a cursory glance would suggest. For example, a high degree of reliance on private management may favor

'Agenda 21, Chapter 11, Combatting deforestation. Advance copy. Conches, Switzerland: United Nations Conference on Environment and Development, 14 June 1992; 22 p. 1. 
production of tangible (marketable) commodities at levels more beneficial to current, rather than future, generations. A high proportion of managed forests is cause for alarm among those who equate management with ecosystem simplification and loss of diversity. Temperate zone forests that support sustained production of industrial commodities differ from unmanaged, undisturbed forests. Lack of scientific and social information limits our ability to state comfortably that all biological, climatic, and social contributions of forests are being maintained.

In addition, many aspects of U.S. experience with forests-or, more broadly, the experience of developed, temperate zone countries-may not be relevant to tropical developing countries. For example, Kuusela (1992b) described the positive consequences of shifting cultivation on the boreal forests of Finland and Russia. This pattern of use characterized $50 \%$ to $75 \%$ of Finland's forests before the 20th century. Trees that would otherwise have been replaced through succession were perpetuated, resulting in good soil fertility, and diverse plant and animal communities (Kuusela 1992a). Whether similar types of forest use in the tropics could produce similar results is a matter of debate and uncertainty. Although some argue that human-caused canopy openings in the tropical forest result in similar increases in diversity of landscapes, plants, and animals, low intensity shifting cultivation is no longer the typical human use of tropical forests.

In many, but not all respects, the institutions and accomplishments of U.S. forestry present a positive role model; however, it is important to examine the factors that contributed to the difference between U.S. forests today and the forests of 100 years ago. The forestry accomplishments of the United States have been based on good fortune, temperate forest biology, and the strength of U.S. institutions:

- The wealth of the initial endowment of land resources, both agricultural and forest, provided a significant reserve for an expanding, industrializing country. Our ability to draw on and adapt to the diverse forest resources of one-half a continent provided opportunities to begin inefficiently, to learn as we went along, and to apply the lessons learned. Fortuitous developments in agriculture, transportation, and the structure of the economy had enormous, beneficial impacts on U.S. forests in the late 19th and early 20 th century.
- The forest resources have proven to be largely resilient ecosystems, capable of producing a broad range of products and services. Temperate forest ecosystems are capable of adapting to significant alterations in patterns and intensities of disturbances and, under a broad range of conditions, are capable of regenerating naturally to productive forests. It is not clear that tropical forestecosystems share these biological characteristics.

- The United States developed powerful, stable, social and political institutions; prominent among these are the significant role for private ownership and management, the importance of free markets, public participation in federal, state, and local resource management and policy formulation, and the use of a variety of policy tools implemented by all levels of government.

If these are elements in U.S. success with forests, then we must consider how often similar conditions are found among tropical developing countries. Aspects of U.S. experience that can form the basis of efforts to export U.S. success include the importance of stable social and political institutions governing uses of forest land, the importance of developments outside the forest sector, and the application of technology to resource assessment, planning, and management. Communicating the importance and nature of effective institutions, determining methods for application of technical skills, and developing an understanding that efforts to effect change in forest conditions in developing countries may need to focus attention on policies outside the traditional domain of the forest sector and forest policy, are among the exports the United States can offer.

\section{Summary}

For more than 100 years, the condition of natural resources in the United States has been affected by global resources. In the most narrow sense, the effects of global resources have been felt through the fact that we import resources to sustain consumption, and we export production from our domestic resources to sustain industries and economic growth. The observation that the United States is part of a global economy is as true for the forest sector as for any sector of theU.S. economy. We also have become more aware of the way in which we 
are part of a global environment. This global awareness grows out of increased attention to the environmental and amenity services provided by domestic natural resources, as well as a recognition of the magnitude and extent of global environmental impacts resulting from activities cumulating across nations, and over time.

Consideration of the capabilities and conditions of U.S. forests, as required by the RPA, must fully take into account international dimensions of U.S. forests. These dimensions include the importance and conditions of U.S. forests relative to forests of the rest of the world; the effects of the United States on forests of other nations; and the objectives, means, and extent to which the United States can effect changes in global forest conditions.

Deliberate or not, and direct or not, the United States has had, and will continue to have a significant impact on global forests. In turn, we increasingly recognize the impact of global forests on the United States. Perhaps the greatest impacts originating in the United States are simply a consequence of the magnitude of the U.S. economy. The forest products sector, although small in comparison to the total U.S. economy, is significant on a global scale; the United States leads the world in production and consumption of forest products. At the same time, as one of the world's leading nations, the United States is increasingly challenged to develop, advocate, and defend positions that are consistent with our behavior and sustainable in both a political and an environmental sense. The emergence of international environmental diplomacy is a natural consequence of the importance of global environmental conditions and transboundary environmental impacts. Defining national interest, and a U.S. role in international approaches to global environmental problems may be the most significant challenge for U.S. resource policy in the 1990s. The efforts of non-government organizations with international concerns result in pressure for continuity in U.S. policy, as well as consistency between domestic environmental policy and international resource policy (Caldwell 1988).

By understanding U.S. forests in a global context, and understanding the scope, origin, and importance of U.S. forestconservation and managementaccomplishments, the United States can participate effectively in debating and addressing global forest issues. Through this process, we can better understand the implications of international resource issues for U.S. forests and, at the same time, identify circumstances where the transfer of U.S. experience to other countries is both relevant and wel- come. Our increasing awareness of the global context in which our forests, communities, and economy exist inevitably will change the ways we use and manage our own resources..

\section{Literature Cited}

Allen, J. C.; Barnes. D. F. 1985. The causes of deforestation in developing countries. Annals, Asso. American Geographers. 75: 163-84.

Allan, T; Lanly, J. P. 1991. Overview of status and trends of world's forests. In: Howlett, D.; Sargent, C., editors. Technical Workshop to Explore Options for Global Forestry Management. Proceedings of a workshop. 24-30 April 1991; Bangkok, Thailand. London: International Institutefor Environmentand Development. 17-39.

Arnold, Mike. 1991. Forestry expansion: and study of technical, economic, and ecological factors; the long term global demand for and supply of wood. Paper 3. Oxford: Oxford Forestry Institute. 22 p.

Barraclough, Solon; Ghimire, Khrishna. 1990. The social dynamics of deforestation in developing countries: principal issues and research priorities. Discussion paper 16. Geneva: United Nations Research Institute for Social Development. $40 \mathrm{p}$.

Bowyer, Jim L. 1992. Responsible environmentalism: the ethical features of forest harvest and wood use on a global scale. Forest Perspectives. 1(4):12-14.

Caldwell, Lynton K. 1988. Beyond environmental diplomacy: the changing institutional structure of international cooperation. In: Carroll, John E., editor. International environmental diplomacy. Cambridge: Cambridge University Press. 13-27.

DeBeer,Jenne; McDermott, Melanie. 1989. The economic value of non-timber forest products in Southeast Asia.Amsterdam: NetherlandsCommittee for IUCN. $175 \mathrm{p}$.

de Montalembert, M. R.; Clement, J. 1983. Fuelwood supplies in developing countries. Forestry Pap. 42. Rome: United Nations, Food and Agriculture Organization.

Dembner, S. 1991. Provisional data from the Forest Resources Assessment 1990 project. Unasylva. 42(164):40-44.

Downing, Theodore E; Hecht, Susanna B.; and others. 1992. Development or destruction: the conversion of forest to pasture in Latin America. Boulder, CO: Westview Press. 405 p. 
Evans, J. 1986. Plantation forestry in the tropics - trends and prospects. International Tree Crops Jour. 4:3-15.

Food and Agriculture Organization. 1963. World forest inventory. Rome: United Nations. 113 p.

Food and AgricultureOrganization. 1967. Timber trends and prospects in Africa. Rome: United Nations. 90 p.

Food and Agriculture Organization. 1976. Forest resources in the European region. Rome: United Nations. 31 p.

Food and Agriculture Organization. 1982. World forest products demand and supply 1990 and 2000. Forestry Pap. 29. Rome: United Nations.

Food and Agriculture Organization. 1985. Forest resources 1980. Rome: United Nations. 19.p.

Food and Agriculture Organization. 1986. World forest products demand and supply 1990 and 2000. Forestry Pap. 73. Rome: United Nations. 101 p.

Food and Agriculture Organization. 1991. Forest products: world outlook projections. Forestry paper 84 . Rome: United Nations. vol. 1, 190 p.; vol. 2, 361 p.

Food and Agriculture Organization. 1992a. Yearbook of forest products. Forestry series 25. Rome: United Nations, Food and Agriculture Organization. 332 p. Food and Agriculture Organization. 1992b. The forest resources of the tropical zone by main ecological regions. Rio de Janeiro, Brazil: United Nations Conference on Environment and Development. 30 p.

Grainger, Alan. 1990. Modeling deforestation in the humid tropics. In: Palo, M.; Mery, G, editors. Deforestation or development in the Third World? Bull. 349. Helsinki: Finnish Forest Research Institute. 51-67.

Grainger, A. 1988. Future supplies of high-grade tropical hardwoods from intensive plantations. Jour. World Forest Res. Mgt. 3:15-29.

Gregersen, Hans. 1992. Key forestry issues facing developing countries: a focus on policy and socioeconomic research needs. In: Gregersen, Hans; Oram, Peter; Spears, John. Priorities for forestry and agroforestry policy research: report of an international workshop. Washington, DC: International Food Policy Research Institute (IFPRI). 55-62.

Guppy, Nicholas. 1984. Tropical deforestation: a global view. Foreign Affairs. 62(4):928-965.

Howlett, David; Sargent, Caroline, editors. 1991. Technical workshop to explore options for global forestry management. Proceedings of a workshop. Bangkok, Thailand; 24-30 April, 1991. London: International InstituteforEnvironmentand Development(IIED).349 p.

Huguet, L. 1983. The future of the world's tropical forests. Common. Forestry Rev. 62:195-200.
Kallio, Markku; Dykstra, Dennis P.; Binkley, Clark S. editors. 1987. The global forest sector: an analytical perspective. New York: John Wiley and Sons. 706 p.

Kramer, Randall; Healy, Robert; Mendelsohn, Robert. 1992. In: Sharma, Narendra, editor. Managing the world's forests: looking for balance between conservation and development. Dubuque, Iowa: Kendall Hunt. 237-267.

Kuusela, K. 1987. Forest products - world situation. Ambio. 16:80-85.

Kuusela, K. 1992a. Boreal forestry in Finland: a fire ecology without fire. Unasylva. 170(43):22-25.

Kuusela, K. 1992b. The boreal forests: an overview. Unasylva. 170(43):3-13.

Lanly, J.P.; Clement, J. 1979. Present and future forest and plantation areas in the tropics. FAO:MISC/79/1. Rome: United Nations, Food and Agriculture Organization.

Laarman, Jan G.; Sedjo, Roger A. 1992. Global forests: issues for 6 billion people. New York: McGraw-Hill. $337 \mathrm{p}$.

Lanly, Jean-Paul. 1982. Tropical forest resources. Forestry paper 30 . Rome: United Nations, Food and Agriculture Organization. 106 p.

Mahar, Dennis J. 1989. Government policies and deforestation in Brazil's Amazon region. Washington, DC: World Bank. 56 p.

Maini, J. S. 1991. Toward an international instrument on forests. In: Howlett, David; Sargent, Caroline, editors. David Howlett and Caroline Sargent, editors. Technical workshop to explore options for global forestry management. Proceedings of a workshop. Bangkok, Thailand; 24-30 April, 1991. London: International Institute for Environment and Development (IIED). 278-285. 349 p.

Marsh. G. P. 1884. Man and nature. New York: Charles Scribner and Sons. 629 p.

Mather, A. 1990. Global forest resources. Portland, OR: Timber Press. 341 p.

Mather, A. 1987. Global trends in forest resources. Geography. 72(314):1-15.

National Research Council. 1990. Forest research: a mandatefor change. Washington, DC:National Academy Press. 84 p.

National Research Council. 1991. Tropical forestry research: developing a U.S. strategy. Washington, DC: Board on Science and Technology for International Development. $56 \mathrm{p}$.

Osara, N. A. 1984. World forestry: some trends and prospects. Acta Forestalia Fennica. 190:91-107. 
Panayotou, Theodore; Ashton, Peter. 1992. Not by timber alone: economics and ecology for sustaining tropical forests. Washington, DC: Island Press. 282 p.

Paterson, Sten Sture. 1956. The forest area of the world and its potential productivity. Göteborg, Sweden: Royal University of Göteborg, Department of Geography. 216 p.

Persson, Reidar. 1974. World forest resources: review of the world's forest resources in the early 1970s. Res. Note 17. Stockholm: Royal College of Forestry, Department of Forest Survey. 265 p.

Persson, Reidar. 1977. Forest resources of Africa. Res. Note 22. Stockholm: Royal College of Forestry, Department of Forest Survey. 224 p.

Powell, Douglas S.; Faulkner, Joanne S.; Zhu, Zhiliang; MacCleery, Douglas W. (in press). Forest resources of the United States, 1992. Gen. Tech. Rep. Fort Collins, CO: U.S. Department of Agriculture, Forest Service. [In press]

Pringle,S. 1976. Tropical moist forests in world demand, supply, and trade. Unasylva. 28(112-113):106-118.

Repetto, Robert; Gillis, Malcolm, editors. 1988. Public policies and the misuse of forest resources. Cambridge: Cambridge University Press. 432 p.

Richards, John F.; Tucker, Richard P., editors. 1988. World deforestation in the twentieth century. Durham, NC: Duke University Press. 321 p.

Schallau, Con H.; Goetzl, Alberto. 1992. Effects of constraining US timber supplies. Journal of Forestry. 90(7):22-27.

Schlosser, William E.; Blatner, Kieth A.; Chapman, Roger C. 1991. Economic and marketing implications of special forest products harvest in the coastal Pacific Northwest. Western Journal of Applied Forestry. 6(3):67-72.

Sedjo, Roger. 1980. Forest plantations in Brazil and their possible effects on world pulp markets. Journal of Forestry. 78:702-704.

Sedjo, Roger. 1981. World forest plantations-what are the implications for U.S. forest products trade? In: Sedjo, Roger, editor. Issues in U.S. international forest products trade. Res. Pap. R-23, Washington, DC: Resources for the Future. 17-39.

Sedjo, Roger. 1987. Forest resources of the world: forests in transition. In: Kallio, Markku; Dykstra, Dennis P.; Binkley, Clark S. editors. 1987. The global forest sector: an analytical perspective. New York: John Wiley and Sons. 7-31.706 p.
Sedjo, R.; Clawson, M. 1984. Global forests. In: Simon, J. L., Kahn, H., editors. Resourceful Earth. Oxford: Basil Blackwell. 28-170.

Sharma, Narendra P.,editor.1992. Managing the world's forests: looking for balance between conservation and development. Dubuque, Iowa: Kendall Hunt. $605 \mathrm{p}$.

Sommer, A. 1976. Attempt at assessment of the world's tropical forests. Unasylva. 28(112-113):5-25.

Szaro, Robert. 1992. The status of forest biodiversity in North America. Journal of Tropical Forest Science. [In press]

Tucker, Richard P.; Richards, John F. 1983. Global deforestation and the nineteenth-century world economy. Durham, NC: Duke University Press. 210 p.

United Nations, Economic Commission for Europe(UNECE). 1985. The forest resources of the ECE region. ECE/TIM/27. Geneva: United Nations. 223 p.

United Nations, Economic Commission for Europe(UNECE). 1986. European timber trends and prospects to the year 2000 and beyond. ECE/TIM/30. Geneva: United Nations. 2 vols: 323 p. 253 p.

United Nations, Economic Commission for Europe(UNECE). 1992a. The forest resources of the temperate zones: The UN-ECE/FAO 1990 forest resource assessment. ECE/TIM/62. Geneva: United Nations. $348 \mathrm{p}$.

United Nations, Economic Commission for Europe(UNECE). 1992b. The forest resources of the temperate zones: Main findings of the UN-ECE/FAO 1990 forest resource assessment. ECE/TIM/60. Geneva: United Nations. 32 p.

United Nations. 1992. Conservation and development of forests. A/CONF/.151/PC/64. Rio de Janeiro, Brazil: United Nations Conference on Environment and Development. 48 p.

U.S. Department of Agriculture, Forest Service. 1988. The South's fourth forest: alternatives for the future. Res. Rep. 24. Washington, DC. 512 p.

U.S.Department of Agriculture, ForestService. 1989. An analysis of the land base situation in the United States: 1989-2040. Gen. Tech. Rep. RM-181. Fort Collins, CO: Rocky Mountain Forest and Range Experiment Station. 76 p.

U.S. Laws, Statutes, etc.; Forest and Rangeland Renewable Resources Planning Act. Act of Aug. 17, 1974. 88 Stat. 476, as amended; 16 U.S.C. 1600-1614. 
Whelan, Tensie. 1991. Ecotourism and its role in sustainable development. In: Whelan, Tensie, editor. Nature Tourism: managing for the environment. Washington, DC: Island Press. 1-22.

Wickens, G. E. 1991. Management issues for development of non-timber forest products. Unasylva. 165(42):3-8.
World Resources Institute. 1992. World resources 199293. Oxford: Oxford University Press. 385 p.

Zon, Raphael. 1910. Forest resources of the world. Bull. 83. Washington, DC:U.S. Department of Agriculture, Forest Service.

Zon, R.; Sparhawk, W. W. 1923. Forest resources of the world. New York: McGraw-Hill. 2 vols. 


